\title{
DEBATA
}

\section{CHINY - UNIA EUROPEJSKA - STANY ZJEDNOCZONE: WYZWANIA W XXI WIEKU}

Zapis konferencji zorganizowanej przez Fundację „Polska w Europie” oraz Centrum Cywilizacji Azji Wschodniej Szkoły Wyższej Psychologii Społecznej w Warszawie, w dniu 28 lutego 2006 r.

\section{Krzysztof Gawlikowski}

Witam panelistów i wszystkich gości na konferencji: „Chiny - Unia Europejska Stany Zjednoczone: nowe wyzwania w XXI wieku". Wypełniona sala wskazuje, iż coraz więcej osób dostrzega znaczenie przemian zachodzących w świecie i kształtowania nowego układu sił, w którym Chiny odgrywają coraz większą rolę. Ponieważ gości nas Szkoła Wyższa Psychologii Społecznej, zajmująca się w coraz szerszym zakresie sprawami Azji i stosunków międzynarodowych, chciałby państwa powitać rektor naszej szkoły, Jego Magnificencja profesor Andrzej Eljasz.

\section{Andrzej Eljasz}

Witam państwa bardzo serdecznie. Zaszczytem dla naszej uczelni jest goszczenie tak znakomitego grona. Cieszę się ogromnie, że państwo tutaj przybyli. Problematyka dzisiejszego spotkania, jak państwo wiedzą, jest niezwykle ważna dla świata i dla Polski - poprzez członkostwo w Unii Europejskiej coraz szerzej włączanej w procesy globalizacji. Wdzięczny jestem profesorowi Gawlikowskiemu, że zaproponował takie spotkanie, a państwu dziękuję za przybycie. Życzę pomyślnych obrad.

\section{Krzysztof Gawlikowski}

Dziękuję bardzo, panie Rektorze. Dzisiejszemu spotkaniu będziemy współprzewodniczyć razem z Panem Zygmuntem Skórzyńskim, świetnie znanym znakomitej większości państwa. Panelowa forma, którą dzisiaj zastosowaliśmy, jest stale stosowana przez prowadzoną przez niego Fundację „Polska w Europie”. Sam kilkakroć miałem zaszczyt występować w tych panelach i bardzo mi się ta formuła podobała, stąd przenieśliśmy ją tutaj, na nasze spotkanie azjatyckie.

Jako referenci w naszym panelu wystapią: profesor Ryszard Piasecki z Uniwersytetu Łódzkiego, znakomity specjalista zajmujący się gospodarką światową, profesor 
Edward Haliżak, dyrektor Instytutu Stosunków Międzynarodowych na Uniwersytecie Warszawskim i czołowy u nas badacz Azji Wschodniej, jak też profesor Jan Rowiński, wieloletni dyplomata pracujący w MSZ i w naszej Ambasadzie w Pekinie, a także jeden z najwybitniejszych w Polsce badaczy polityki wewnętrznej i zagranicznej Chin. Chciałem zarazem państwa przeprosić, iż nie ma z nami ministra Adama D. Rotfelda, który niestety musiał wyjechać do Waszyngtonu, a pan minister Witold Waszczykowski, który miał też dzisiaj wystapić, przejął chwilowo kierowanie resortem, ponieważ minister Stefan Meller jest chory. W trybie awaryjnym udało się nam zaprosić znakomitego specjalistę z MSZ, pana doktora Henryka Szlajfera, który łączy zainteresowania polityczne i dyplomatyczne z naukowymi, a jest świetnym znawcą spraw amerykańskich i europejskich. Mam więc nadzieję, że zastapi nam poniekąd brakujących panelistów.

Pragnę jeszcze dodać, że w SWPS zajmujemy się od kilku lat, coraz szerzej, sprawami azjatyckimi. Studenci mogą korzystać z rozmaitych zajęć o Azji Wschodniej studiując politologię, socjologię, czy inicjowane w tym roku stosunki międzynarodowe. Działa tu trzyletnia szkoła języka chińskiego, oferujemy elementarny kurs języka birmańskiego (uczymy także języka arabskiego, a nauka innych języków orientalnych jest przygotowywana). Zajęcia te koordynowane są przez Centrum Cywilizacji Azji Wschodniej SWPS. W bieżącym roku rozpoczynamy duży program rozwoju Działu Orientalnego naszej biblioteki, tworzonego przez dr Małgorzatę Ławacz. Jeśli ktoś z państwa zajrzy na stronę internetową SWPS, znajdzie tam informacje o naszej szkole nie tylko w języku angielskim ale także w chińskim. To chyba jedna z pierwszych uczelni polskich, która ma stronę po chińsku i - jak słyszałem - przybywają do nas pierwsze grupy studentów z Chin. Zatem nasze teoretyczne zainteresowania regionem łączą się tutaj po trosze z praktyką.

Chciałbym teraz prosić pana profesora Ryszarda Piaseckiego z Uniwersytetu Łódzkiego o pierwsze wystapienie panelowe.

\section{Ryszard Piasecki}

Proszę państwa, temat naszej dzisiejszej konferencji jest ogromny: Chiny, Unia Europejska, Stany Zjednoczone wobec wyzwań XXI wieku. Rozumiem, że będziemy się koncentrować przede wszystkim na Chinach, bo chyba na tym rzecz polega, żeby spróbować zgłębić przyczyny sukcesu tego kraju, które są dla wielu ekonomistów zaskakujące. Zanim rozpoczęliśmy to spotkanie, miałem okazję zamienić kilka zdań z panem profesorem Kowalikiem. I dla ekonomistów rzeczywiście jest to problem. Właściwie sukces Chin nie powinien był nastapić z punktu widzenia, przykładowo, reguł Konsensusu Waszyngtońskiego. Jeśli przyjrzymy się problematyce rozwojowej krajów Trzeciego Świata po drugiej wojnie światowej, to widzimy, że mamy do czynienia z pewnego rodzaju ciagłym falowaniem: od entuzjazmu po poczucie porażki. Popatrzmy na ostatni okres - od połowy lat 80. do chwili obecnej, czyli okres stosowania w wielu krajach recepty liberalnej rozwoju zwanej Konsensusem Waszyngtońskim. Wydawałoby się, że już lepszej receptury na rozwój gospodarczy krajów słabiej rozwiniętych być nie może. Tymczasem wielu specjalistów ma poczucie niedosytu, ponieważ konsensus ten nie dokonał zasad- 
niczego przełomu w rozwoju gospodarczym. Okazało się, że główne filary konsensusu, czyli deregulacja, prywatyzacja i liberalizacja, nie wystarczyły do uruchomienia procesów rozwojowych. Zabrakło efektywnej konkurencji i odpowiednich instytucji. Taką znaną instytucją rynkową są, przykładowo, prawa własności (property rights). Czy są one powszechnie respektowane w krajach słabo rozwiniętych? Wiadomo, że nie. Znany amerykański ekonomista D. Rodrik wymienia tu szereg instytucji niezbędnych do funkcjonowania gospodarki kapitalistycznej (instytucje tworzące rynek, instytucje regulujące rynek, instytucje osłonowe). A więc można powiedzieć, że sukces gospodarczy w wielu krajach stosujących receptę liberalną jest wątpliwy, albo jeszcze nie nastąpił.

I oto mamy Chiny, które od 1978 r. realizuja program reform, w istocie rynkowych, które zaskoczyły wielu specjalistów. Od 28 lat realizują rocznie - tak się mówi - 8-10\% tempa wzrostu gospodarczego. Co prawda nie wszyscy specjaliści się do końca z tym zgadzaja, powatpiewając, czy to są rzeczywiście prawdziwe cyfry. My nie jesteśmy w stanie ich zweryfikować i dlatego należy przyjąć, że są raczej prawdziwe. Rozwój gospodarczy Chin trudno zakwestionować. Niewatpliwie mamy do czynienia z szybkim rozwojem i sukcesem gospodarczym tego kraju. Dla ekonomistów pojawia się w tym miejscu pytanie, gdzie leży przyczyna tego sukcesu, i jak to jest możliwe, żeby osiagnął go kraj, nie mający ani demokracji, ani prawdziwej gospodarki rynkowej. Nie jest to oczywiście znany nam model socjalistyczny - dlatego, że dzisiaj $60 \%$ własności w Chinach to jest własność niepaństwowa, nawet jeśli nie jest to w pełni własność prywatna. To jest kraj, który się niebywale otworzył na zewnątrz, i to jest kraj który - muszę państwu powiedzieć - jest drugim, jeśli chodzi o ilość bezpośrednich inwestycji zagranicznych. A więc to nie jest to samo. Także kulturowo, to nie jest ta sama strefa - to jest kraj konfucjańskiej filozofii zupełnie innego stosunku do pracy i prawa. Tym niemniej faktem jest, że jest to kraj, który demokracji w naszym rozumieniu nie posiada. A więc, co się zdarzyło w Chinach? Otóż niewatpliwie w ciagu tego okresu nastapił tu wzrost dobrobytu. Według najnowszych danych poziom PKB na głowę mieszkańca wynosi 1100 dolarów, ale z punktu widzenia purchasing power parity mamy zupełnie inną sytuację. To jest $13 \%$ siły nabywczej Stanów Zjednoczonych, czyli około 5000 dolarów na mieszkańca. A to już jest zupełnie inna sytuacja. Dla przykładu, Indie mają tylko $7 \%$, a Polska ma 30\% siły nabywczej USA. A zatem chińskie 13\% jest bardzo znaczące. Co jeszcze nastapiło? Wzrost eksportu tego kraju jest niebywały i to jest niezwykle imponujące. Mówi się, że dzisiaj $21 \%$ eksportu jest kierowane do Stanów Zjednoczonych, 18\% do Hongkongu. Jest to rzeczywiście kraj, który ma kolosalne sukcesy eksportowe mimo tego, że osiagnięte one zostały głównie przez korporacje wielonarodowe. Mówi się, że Chiny podjęły wielkie wyzwanie przejścia od XIX do XXI wieku. Jest to dzisiaj potęga gospodarcza świata o bardzo rozwiniętym przemyśle przetwórczym - w przeciwieństwie do Indii, które mają rozwinięty, przede wszystkim, sektor usługowy. No i, jak powiedziałem, $60 \%$ PKB to jest sektor prywatny i niepaństwowy. Wróćmy teraz do innych problemów. Z jednej strony mamy niewątpliwy sukces Chin i jest on niekwestionowany. Ale $\mathrm{z}$ drugiej strony pojawiły się również bardzo poważne problemy społeczne związane z rozwojem. Wszyscy specjaliści zadają sobie pytanie, czy to jest rozwój trwały i czy można powiedzieć, że za 10, za 20 lat kraj ten będzie się dalej podobnie rozwijał. Trudno udzielić jednoznacznej odpowiedzi. 
9\% wzrostu gospodarczego rocznie - to jest rezultat imponujący dla ekonomistów, wręcz nieprawdopodobny. Skąd taka dynamika wzrostu z roku na rok jest możliwa?

Kolejna sprawa. W Chinach, w wyniku realizacji programu relatywnej wolności gospodarczej, nastąpił szybki wzrost nierówności społecznych. Według różnych informacji, które tutaj posiadam, dzisiaj różnica pomiędzy poszczególnymi regionami jest jak 6:1. Są regiony bardzo bogate i są regiony szalenie ubogie. Relacja między miastem a wsią, jest jak 3:1. Kiedy dwa lata temu byłem w University of British Columbia w Vancouver i usiłowałem namówić Kanadyjczyków do przyjazdu do Polski, w ramach realizacji programu MBA, oni powiedzieli, owszem przyjedziemy, ale to kosztuje 26000 dolarów. Ja mówię, „to jest zbyt wysoka kwota, żeby dało się ten program zaproponować na polskich uniwersytetach”. A oni na to: „W Chinach, w Szanghaju mamy stu studentów, którzy właśnie płacą po 26000 dolarów rocznie". Widzimy takie okolice, jak Szanghaj i Pekin, które są bardzo bogate, a jednocześnie mamy obszary nieprawdopodobnie ubogie. Nastąpił wzrost nierówności społecznych, właściwie do przewidzenia przy tak szybkim tempie wzrostu gospodarczego. Dalej, według różnych informacji, które napływaja, w 2003 r. zarejestrowano w Chinach 58.000 protestów społecznych, ale w roku 2004 było ich już 80.000 .

Kolejny problem na jaki się zwraca uwagę, to korupcja. Wreszcie - negatywne konsekwencje ekologiczne przyspieszonego wzrostu gospodarczego. Wzrost gospodarczy w Chinach jest przede wszystkim uzależniony od eksportu, co rodzi w sposób oczywisty napięcia z innymi partnerami handlowymi na świecie. To, co się dzieje w Chinach jest dość charakterystyczne dla społeczeństw, które przekraczają poziom 2-3 tysięcy dolarów PKB na głowę mieszkańca. To wtedy zaczynają się te nierówności i zaczynają się niepokoje społeczne. Do 2-3 tysięcy USD na mieszkańca rocznie niepokojów społecznych na ogół nie ma. W związku z tym zaostrzają się w Chinach problemy społeczne. Poza tym, jak się ocenia, Chiny mają niesprawny sektor finansowy. Także sektor bankowy jest generalnie niesprawny. Możemy mieć różne podejścia do tej sprawy, ale faktem jest, że znaczenie Chin w rozwoju gospodarczym dzisiejszego świata jest kolosalne.

Czy ten rozwój jest szybszy, czy wzrost gospodarczy jest mniejszy czy większy - tego nie jesteśmy w stanie ustalić, ale ogromne znaczenie Chin w gospodarce światowej jest dzisiaj faktem niepodważalnym W ostatnich latach chiński wzrost gospodarczy rodzi ogromny nacisk na zasoby światowe, zasoby surowcowe i tak dalej. Widzieliśmy w Polsce nagle wzrost popytu na stal w związku z ogromnym popytem na ten surowiec w Chinach. Czyli to, co się dzieje w Chinach dziś jest odczuwalne dla wszystkich. Tu pojawia się dość istotne pytanie często stawiane przez specjalistów: co się stanie na świecie jeśli ten model gospodarczy w Chinach okaże się sukcesem i Chińczycy będą zmierzali w perspektywie kilkunastu czy kilkudziesięciu lat do modelu konsumpcji zbliżonego do krajów zachodnich? Artykułów jest tutaj mnóstwo, ale wszystkie są katastroficzne, Jeśli tak się w Chinach stanie - a do tego niedługo dojdą Indusi, bo rozwój w Indiach jest równie szybki - to już teraz przewiduje się kolosalne konsekwencje ekologiczne, kurczenie się zasobów. Mówi się nawet o tym, że Amazonia musi być zlikwidowana, żeby wyżywić Chiny przy tym nowym poziomie konsumpcji. 
Jaki z tego wniosek? Otóż wniosek jest taki, że nie możemy przewidzieć, czy Chiny będą się rozwijały przez najbliższe lata tak szybko, czy nie. Ale mogą się rozwijać biorąc pod uwagę, że już od 28 lat rozwijają się tak szybko. I dalej - przy istniejącym modelu rozwoju gospodarczego na świecie, świat nie udźwignie tej sytuacji. Dzisiejszy chiński model konsumpcji (a w perspektywie także hinduski, chociaż Indusi są dalej, mając dochód dwa razy niższy - 560 dolarów na głowę) jeszcze nie stwarza takiej sytuacji, ale perspektywy pod tym względem są dość niepokojące. Świat musi zmienić swój model gospodarowania. Mówię o wysoko rozwiniętych krajach. Przede wszystkim myślę o położeniu akcentu na odnawialną energię, a nie na tę energię, która się kryje w zasobach Ziemi, czyli ropę naftową. Dalej, konieczna jest zmiana priorytetów transportowych. Trudno sobie wyobrazić w Chinach przyjęcie na masową skalę modelu indywidualnego środka transportowego - samochodu - na poziomie amerykańskim. To jest niemożliwe, dlatego, że również nacisk na istniejące zasoby będzie kolosalny i będzie on nie do udźwignięcia w obecnych warunkach. Dalej, kwestia odtwarzania zużytych materiałów, czyli cała procedura recyklingu, jest także bardzo istotna. Wreszcie, konieczne jest zmierzanie do zerowej emisji zanieczyszczeń, czy też do zerowego marnotrawstwa. To jest model gospodarczy, przy którym świat może sobie poradzić w przypadku gdyby rozwój Chin (i Indii) następował tak szybko jak następuje. Jeśli świat rozwinięty nie zmieni tego modelu, to już dzisiaj widać konsekwencje - rosnący popyt na ropę naftową ze wszystkimi negatywnymi tego skutkami. Czyli, nie możemy zahamować rozwoju Chin, a wręcz przeciwnie - to jest oczywiste - niech się rozwijają, bo to jest w interesie świata, również Indii. Ale istniejący model rozwoju gospodarczego musi być zmieniony. To poddaje państwu pod dyskusję. A tak na marginesie: Chiny wydają na naukę $2,1 \%$ swojego PKB, $2,5 \%$ nawet, a Polska $0,6 \%$ - podaję to jako swoistą ciekawostkę.

\section{Edward Haliżak}

Zostałem poproszony o przedstawienie tu kilku uwag na temat stosunków chińskoamerykańskich. Byłoby truizmem stwierdzenie, że stosunki chińsko-amerykańskie uważane są obecnie za najważniejsze bilateralne relacje we współczesnych stosunkach międzynarodowych. Zdaniem wielu obserwatorów, stosunki te - pod względem ich znaczenia dla świata - przypominają stosunki Związek Radziecki - Chiny z epoki zimnej wojny. W moim przekonaniu - a jest też wielu specjalistów, którzy zgadzają się z tym poglądem - takie porównanie nie jest uprawnione. Brakuje przecież w nich elementu walki ideologicznej, starcia ideologicznego na wielu płaszczyznach, mimo istniejących różnic ustrojowych. Ani USA, ani Chiny nie traktują dzisiaj siebie jako konkurentów ideologicznych, czy reprezentantów przeciwstawnych opcji, chociaż inaczej przedstawiają siebie i swoje ideały. Ponadto ani w oficjalnych enuncjacjach, $w$ doktrynach bezpieczeństwa narodowego, czy w dokumentach politycznych nie określa się drugiej strony jako przeciwnika, którego ideologię należy wszelkimi sposobami zwalczać, tak jak miało to miejsce w przeszłości. Co o tym decyduje?

Przede wszystkim Chiny nie kwestionują roli Stanów Zjednoczonych w świecie. Akceptują ich rolę globalną i regionalną w Azji Wschodniej, a nawet uważają obecność 
Stanów Zjednoczonych w tym regionie oraz na obszarze Pacyfiku za rzecz całkiem pożyteczną. Traktują zaangażowanie ich w Azji jako sytuację korzystną dla Chin dlatego, że w przeciwnym przypadku musiałyby, na przykład, zapewnić - na własny koszt - bezpieczeństwo morskich szlaków komunikacyjnych poprzez rozbudowę własnej marynarki wojennej i dalekomorskich sił zbrojnych. Zaangażowanie Stanów Zjednoczonych ogranicza również aspiracje Japonii i jej aktywność w wymiarze strategicznym w Azji Wschodniej, jaka budziłaby duże obawy w Chinach.

Chiny nie prowadzą też antyamerykańskiej krucjaty ideologicznej, nie krytykują amerykańskiego ustroju, ani wartości. Wręcz przeciwnie, jeśli odwołamy się do literatury, to naśladownictwo rozwiązań amerykańskich w sferze gospodarczej oraz instytucji życia społecznego jest wszechobecne. Na przykład, uniwersytety chińskie są reorganizowane na wzór i podobieństwo uniwersytetów amerykańskich. Jesteśmy właśnie teraz Polsce w trakcie dyskusji o systemie „trzy plus dwa” (studia licencjackie i magisterskie), a w Chinach to już zostało dawno rozstrzygnięto. Amerykańskie wzorce dość powszechnie w Chinach uznaje się za „dobre i nowoczesne”.

Ponadto, przywódcy chińscy podkreślają na każdym kroku, że sukcesy w modernizacji ich kraju zależą od współdziałania ze Stanami Zjednoczonymi i obecnie odrzucają konkurowanie z nimi. Jeśli chodzi o Stany Zjednoczone, to w moim przekonaniu cechuje je wyjątkowa wrażliwość na wszelkie kwestie związane z Chinami. Dla nich ten partner $\mathrm{z}$ drugiej strony Pacyfiku to jest wciąż ich niespełnione marzenie - American dream - ,przekształcenia Chin na wzór i podobieństwo Stanów Zjednoczonych”. Historia stosunków amerykańsko-chińskich $\mathrm{w}$ istocie nie jest obciążona negatywnymi wydarzeniami. Wręcz przeciwnie, można nawet mówić o swoistym „braterstwie broni”. To Stany Zjednoczone swoją doktryną „otwartych drzwi” w końcu XIX w. przyczyniły się do utrzymania niepodległości Chin, a hamowania dążeń do ich podbojów kolonialnych ze strony innych mocarstw po wojnie chińsko-japońskiej 1984-1895 r. Z okresu II Wojny Światowej pamiętamy legendę Drogi Birmańskiej - o życiowym znaczeniu dla regionu zachodniego Chin, wciąż kontrolowanego przez rząd narodowy, a odciętego od świata przez japońską okupację terenów wybrzeża i Chin centralnych. Teraz przypomina się też chętnie udział pilotów amerykańskich po stronie sił kuomintangowskich $\mathrm{w}$ walce $\mathrm{z}$ agresją japońską: bronili oni ówczesnej stolicy Chunqingu przed nalotami. Jedynym okresem bezpośredniej konfrontacji zbrojnej była wojna w Korei (1950-1953), obecnie w Chinach niemal zapomniana.

Spójrzmy na tę sprawę z punktu widzenia USA. W moim przekonaniu Stany Zjednoczone mają bardzo duży problem w określeniu obecnej roli Chin i swojej polityki wobec nich. Brak jest jednoznacznych ocen politycznych i myśli strategicznej. Z jednej strony argumentuje się, że chiński potencjał militarny wzrasta i podaje się dwucyfrowe dane o jego wzroście. $Z$ drugiej strony, publikuje się liczne analizy, które wykazują rozmaite słabości chińskiego potencjału. Pisze się, np., że tak zwany power projection jest ograniczony tylko do waskiego pasa przybrzeżnego. Chińska marynarka nie posiada żadnych zdolności operacyjnych, prowadzenia działań w odległości większej niż 100 mil. Mało tego, Chiny nie są w stanie przeprowadzić nawet operacji desantowej na Tajwan, bo musiałoby to skończyć się klęską ze względu na brak niezbędnych komponentów 
rzeczowych, jak też logistyki i doświadczenia. Amerykańskie podejście wobec Chin grzeszy pewną ambiwalencją a ujmuja je dwie przeciwstawne formuły: „Chiny jako strategiczny konkurent” i „Chiny jako konstruktywny partner strategiczny”. W zależności od rozwoju sytuacji międzynarodowej, podkreśla się aktualność podejścia pierwszego albo drugiego.

Przed 11 września 2001, nowa administracja George’a W. Busha była skłonna przyjąć założenie, że Chiny są przede wszystkim strategicznym konkurentem. Po tej dacie szybko zmieniono to podejście na strategiczne partnerstwo. Zadecydowały o tym dwa elementy. Przede wszystkim pojawiła się wyjątkowa zbieżność interesów w kwestii fundamentalizmu islamskiego, który jest ważny dla obu stron i podobnie stwarza zagrożenie dla bezpieczeństwa obydwu państw.

Długofalowo występują też w Stanach Zjednoczonych dwa podejścia, osadzone w odmiennym kontekście. $Z$ jednej strony występuje „podejście ekonomiczne”, kiedy uwzględnia się interesy gospodarcze. Amerykańskie firmy i menadżerowie dostają niemal „obłędu w oczach”, kiedy liczą wartość i siłę nabywczą chińskiego rynku, jak też potencjalne dochody oraz interesy, jakie tam można by zrobić. Po drugiej stronie mamy „podejście idealistyczne”, popularne wśród rozmaitych idealistów amerykańskich: aktywistów religijnych, prawicę przywiązaną do amerykańskich wartości, konserwatystów, którzy prowadzą swoją kampanię ideologiczna, a nawet aktywistów demokratów, podobnie mówiących o prawach człowieka, o standardach wykorzystywania siły roboczej, o konieczności demokratyzacji tego państwa, itd. To są dwie opcje, które na każdym szczeblu władzy Stanów Zjednoczonych - ustawodawczej i wykonawczej - ścierają się.

W ostatnim okresie podejście Amerykanów do tego kraju określa koncepcja „Chin rosnących w siłę" (rising China). Jest to termin, który w Stanach zrobił ostatnio kolosalną karierę. Ale z drugiej strony, równie ważne znaczenie ma chyba wyobrażenie „Chin upadających". Jeżeli rosnące w siłę Chiny są zagrożeniem dla USA i ich interesów, zwłaszcza w Azji Wschodniej, to niemal równie wielkim zagrożeniem - z czego zdają sobie sprawę wszyscy analitycy w Stanach Zjednoczonych - byłby upadek Chin. Byłoby to przy tym zagrożenie w ograniczonym stopniu ważne dla samych Chińczyków. Swymi konsekwencjami dotknęłoby zaś przede wszystkim inne gospodarki i państwa, w tym również same Stany Zjednoczone. Uważa się, że mimo statusu supermocarstwa nie posiadają one środków mogących zapobiec katastrofalnym skutkom dla świata, wynikających z głębokiego, ekonomicznego kryzysu Chin. Miałyby ograniczone możliwości przeciwdziałania nawet działając razem ze swoimi sojusznikami. Stąd niebywały paradoks: nikt nie myśli w Stanach Zjednoczonych, by poważnie zaszkodzić Chinom, nawet gdyby przyjąć koncepcję, że jest to strategiczny konkurent.

Związki w sferze gospodarczej są również niejednoznaczne. Stany Zjednoczone notują w handlu z Chinami deficyt rzędu 200 miliardów dolarów. Jest to wynikiem nadwyżki importu. To, rzecz jasna, ma dwojakie konsekwencje. Zabiera to miejsca pracy - co do tego nie ma żadnych wątpliwości - ale w tradycyjnych gałęziach. $Z$ drugiej strony, nie można jednak zapominać o korzyściach. Tani import z Chin jest czynnikiem ograniczającym inflację w Stanach Zjednoczonych. Jest on także dla nich niebywale korzystny i zwiększa siłę nabywczą konsumentów amerykańskich, którzy są bardzo zadowoleni 
mogąc np. kupić towary znanych marek, ale wyprodukowane w Chinach po dużo niższych cenach. Druga, niebywale ważna kwestia. Oto mamy sytuację taką, że Chiny lokując swe nadwyżki dewizowe $\mathrm{w}$ istocie kredytują rozwój gospodarki amerykańskiej. O tym świadczą dane statystyczne: obecnie posiadają one w swym portfelu z tytułu rezerw obligacje amerykańskie wartości 300 miliardów dolarów. To, że Japonia, a także Chiny i inne kraje wschodnioazjatyckie wykupują w tak dużej ilości te właśnie obligacje (także ze względów politycznych), obniża ich cenę rynkową, co sprawia, że finansowanie długu publicznego w Stanach Zjednoczonych jest tańsze i gospodarka amerykańska może uzyskiwać wyższe tempo wzrostu. Leży to zatem $\mathrm{w}$ ich interesie, a wdzięczność $\mathrm{z}$ tego tytułu dla Chin jest w Stanach Zjednoczonych doceniana i często podkreślana.

Jedyną potencjalną dziedziną, która może być przyczyną rywalizacji, jest sfera energii. Stany są największymi importerami i konsumentami ropy naftowej, a Chiny szybko stają się drugim jej gigantycznym importerem. Przy ograniczonych zasobach światowych pojawia się coraz więcej elementów rywalizacji między nimi. W zeszłym roku jedna z firm chińskich chciała przejąć amerykańską firmę naftową. Była to firma niewielka, posiadająca zaledwie 1\% udziału w rynku paliw płynnych, o wartości jakieś 18 miliardów dolarów. Rwetes polityczny, jaki podniósł się w Stanach Zjednoczonych w związku z tą sprawa, momentami przypominał argumenty naszych niektórych partii populistycznych. Wiele perorowano w tym kontekście o zagrożeniu interesów Stanów Zjednoczonych oraz ich bezpieczeństwa itd. A chodziło przecież o firmę małą! Obecnie Chiny starają się nabywać złoża ropy naftowej, lub w inny sposób długoterminowo zapewniać sobie stabilne źródła zaopatrzenia w paliwa. Bliski Wschód i Azja Centralna są potencjalnym miejscem zaopatrzenia Chin w ropę naftową, ale sięgają one także do Afryki i Ameryki Łacińskiej. To zaś rodzi niewątpliwie potrzebę pewnego strategicznego współdziałania, albo grozić może ostrą rywalizacją o dostęp do ropy naftowej.

I wreszcie ostatnia kwestia, która jest kluczowa: sprawa Tajwanu. Otóż zjednoczenie Chin nie leży obecnie w interesie Stanów Zjednoczonych. Nie ma w tej sprawie żadnych wątpliwości, jednak przywódcy tego supermocarstwa nie mówią tego głośno. Podejmowane są natomiast rozmaite działania polityczne, z wciaganiem do tego szeroko organizacji pozarządowych, by umacniać poczucia tożsamości tajwańskiej i utwierdzać mieszkańców tej wyspy w przekonaniu, że są odrębnym społeczeństwem, zasługującym na posiadanie własnego państwa. Nie znam żadnego dokumentu w Stanach Zjednoczonych, który by przewidywał scenariusz zjednoczenia. Biorąc pod uwagę wcale nie jednoznaczne nastroje na wyspie i postępujące procesy integracji gospodarczej z kontynentem, trzeba liczyć się nawet z możliwością uzyskania większości w ewentualnym referendum dla opcji pokojowego zjednoczenia. Na taką okazję przewiduje się użycie rozmaitych pułapek konstytucyjnych i kruczków proceduralnych. Np. obecna administracja wprowadziła wymóg aprobaty większością $3 / 4$, co jest rzeczą niespotykaną nigdzie. Nawet jeżeli $\mathrm{w}$ wyborach parlamentarnych zwyciężyłaby kwalifikowaną większością $50+1$ partia opowiadająca się za zjednoczeniem, to okazałoby się, że nie byłoby możliwe przeprowadzenie tego ze względów formalnych. Wszelkimi środkami wspiera się działania tych ugrupowań politycznych, w tym również obecnej elity prezydenta Chen Shui-biana, które występują przeciwko zjednoczeniu. Podział Chin i ich uzależnienie w tym aspekcie 
od Stanów Zjednoczonych, ogranicza ich możliwości mocarstwowe, a Stany Zjednoczone nazbyt przyzwyczaiły się do tego, że są jedynym supermocarstwem w świecie. Zresztą o tym się mówi w dokumentach amerykańskich dość otwarcie: w interesie Waszyngtonu leży utrzymanie pozycji dominującego mocarstwa w dającej się przewidzieć przyszłości, lub nawet na zawsze. Kwestia Tajwanu w tej sprawie jest zaś kluczowa.

Co prawda, kierując się względami taktyki dyplomatycznej, Stany Zjednoczone prowadzą dość skomplikowaną grę, i to z dużym mistrzostwem. Stosują, na przykład, „zasadę podwójnego odstraszania”. Z jednej strony odstraszają ChRL od użycia siły i zniechęcają tego partnera do opcji militarnej i prób rozwiązania problemu drogą nacisków. Z drugiej zaś strony, odstraszają także rząd na Tajwanie od ogłoszenia niepodległości, co grozić by mogło ogromnymi perturbacjami w Azji Wschodniej i destabilizacją w jej rozwoju. Ponadto obecna sytuacja niejednoznaczności jest dla Waszyngtonu najwygodniejsza. Jednak deklaracjom w duchu ,podwójnego odstraszania” towarzyszy popieranie rozwoju tożsamości tajwańskiej i popieranie przemian na Tajwanie prowadzących do formowania tam społeczeństwa odrębnego i o odmiennej mentalności, blisko związanego z USA. Kwestia, na ile te zamysły są realistyczne, czy na gruncie kultury i cywilizacji chińskiej da się na trwałe dokonać takiego podziału, to sprawa zasługująca na odrębną dyskusję, w przyszłości.

Obecnie niewątpliwie mamy do czynienia z dokonującą się stopniowo zmianą układu sił i wzrostem potęgi Chin, a Stany Zjednoczone niepokoją się o przyszłość jednobiegunowego modelu świata, do którego się już przyzwyczaiły. Jeśli udałoby się utrzymać obecne wskaźniki wzrostu gospodarczego Chin, to oczywiście potencjały ekonomiczne obydwu państw mogłyby się wyrównać już w niezbyt odległej przyszłości, w okresie dwóch - trzech dekad. Ale sam rozmiar gospodarki Chin, a nawet jej nowoczesność, nie przesądzą jeszcze o zajęciu równoważnej pozycji. Niewątpliwie, czeka nas jednak zmiana obecnego porządku międzynarodowego. Z pewnością pojawi się jakiś model dwubiegunowy, chociaż jego charakter trudno dzisiaj przewidzieć. Może on być oparty na konkurencji, albo na współpracy obu partnerów. $Z$ pewnością nie będzie to dwubiegunowość w stylu zimnej wojny, ponieważ elementy współpracy będą nieuchronnie przeważać, gdyż już w tej chwili współzależności ekonomiczne między USA i Chinami są tak wielkie, że nie da się ich zerwać bez szkody dla żadnej ze stron.

Wreszcie kwestia ostatnia. Czy jest możliwy sojusz USA - Chiny? Taka opcja była rozpatrywana w przeszłości. Po II wojnie światowej Stany Zjednoczone, zgodnie ze swą wizją porządku międzynarodowego, chciały uczynić swym głównym sojusznikiem w regionie właśnie Chiny, a nie Japonię. Dopiero tryumf rewolucji komunistycznej w Chinach i ogłoszenie ChRL 1 października 1949 r. zmieniły amerykańskie plany. Japonia stała się więc sojusznikiem zupełnie przez przypadek, tylko dlatego, że wybuchła wojna koreańska, sprowokowana zresztą przez Stalina. Ale dla wielu Amerykanów kwestia współdziałania z Chinami jest bardzo nęcąca, a nadto wydaje się bardzo realistyczna. Po stronie chińskiej jeszcze silniejsza była opcja pro-amerykańska, a podzielały ją rozmaite ugrupowania polityczne. Poglądy takie były obecne nawet w partii komunistycznej, a współcześnie żaden inny kraj nie fascynuje młodych Chińczyków bardziej niż Stany Zjednoczone. One wydają się wzorem i naturalnym głównym partnerem rozkwitających 
Chin. Wariantu ich współpracy nie należy więc odrzucać jako nierealnego. Wskazuje się na przykład, że dwaj odwieczni wrogowie, Francja i Anglia, na przełomie XIX i XX wieku zawarły w końcu porozumienie, tzw. „,serdeczne porozumienie”, które przetrwało najrozmaitsze burze dziejowe XX w. Przez długi czas nie był to sojusz, ale inne formy współdziałania, choć państwa te dzieliło bardzo wiele. Do tego modelu odwołują się niektórzy analitycy rozpatrując kwestię przyszłości stosunków chińsko-amerykańskich.

\section{Jan Rowiński}

Przede wszystkim pragnę powiedzieć, że zadanie postawione przez profesora Gawlikowskiego jest nader trudne - biorąc pod uwagę ogrom tematu i czas na jego prezentację. Siłą rzeczy skoncentruję się skrótowo na najważniejszych sprawach, przepraszając państwa z góry za uproszczenia i potknięcia.

\section{Znaczenie stosunków UE - Chiny.}

Nie ulega wątpliwości, iż skala, rozmach i dynamizm rozwoju stosunków pomiędzy Europą (przede wszystkim Wspólnotą i poszczególnymi państwami członkowskimi) a Chinami jest jednym $\mathrm{z}$ najważniejszych wydarzeń historycznych $\mathrm{w}$ okresie ostatnich $10-15$ lat. Wynika to $z$ reprezentowanego przez obu partnerów potencjału (jako aktualnie drugiego i czwartego „światowego centrum sily”) oraz roli w globalnym, postzimnowojennym układzie sił i w kształtowaniu nowego wyłaniającego się porządku światowego. Myślę, iż jednym z najważniejszych, jeśli nie najważniejszym jej źródłem jest wypracowanie długofalowej, całościowej koncepcji, wielostronnej i zrównoważonej strategicznie, angażowania i współpracy z Chinami na wielu płaszczyznach. Realizowana nie bez trudności i oporów, ale konsekwentnie, doprowadziła wzajemne stosunki na początku XXI w. do poziomu określanego realistycznie mianem ,dojrzewającego (a nie już istniejącego) wszechstronnego partnerstwa strategicznego".

\section{Aktualny stan stosunków}

Główne strategiczne kierunki współpracy zostały określone w dwóch podstawowych dokumentach: A maturing partnership-shared interest and challenges in UE-China relations (Komisja Europejska UE, wrzesień 2003 r.) oraz China's UE Policy Paper (pierwszy tego typu opublikowany, oficjalny dokument rządu ChRL, określający strategię Pekinu wobec innego państwa, październik 2003 r.). W chwili obecnej są przygotowane nowe dokumenty, uwzględniające stan i zmiany, jakie zachodzą w relacjach wzajemnych. 


\section{Najważniejsze płaszczyzny współpracy:}

\section{W sferze politycznei}

\section{W stosunkach wzajemnych na szczeblu unijnym i państwowym:}

Poczynając od 1994 r. stopniowo rozszerzane i podnoszone szczeble instytucjonalizowanych kanałów regularnych konsultacji obejmowały: szczyty UE-ChRL (od 1997 r.), konsultacje ministrów spraw zagranicznych, dyrektorów generalnych, szefów departamentów politycznych, ambasadorów Przedstawicielstw UE w Pekinie i ChRL w Brukseli, spotkań wysokich przedstawicieli rządu ChRL i Komisji Europejskiej itd. oraz niemal 20 tzw. kanałów „dialogu” obejmujących m.in. prawa człowieka, ochronę własności intelektualnej, ochronę środowiska naturalnego, zdrowia, edukacji, ubezpieczeń społecznych, zatrudnienia, współpracy prawnej, naukowo-technicznej, przemysłowej, transportu, finansów, ceł, polityki przemysłowej, lotnictwa cywilnego, informatyki itd..

Należy do tego dodać niezwykle ożywione kontakty państwowe poszczególnych państw członkowskich UE z ChRL, obejmujące wizyty głów państw, szefów rządów, ministrów itd.

\section{We wspótpracy międzynarodowej:}

Konsultacje i, jeśli było to możliwe, koordynację działań w najważniejszych problemach globalnych i sytuacjach kryzysowych, współpracę w ONZ i innych organizacjach międzynarodowych, kwestie dotyczące reformy NZ, problemy strategiczne, bezpieczeństwa, walki z terroryzmem, przestępczością zorganizowana, przemytem narkotyków, kontrolą zbrojeń i rozbrojenia, kwestią nieproliferacji BMR i systemów kontroli środków ich przenoszenia itd.. a także rozwoju, szczególnie dla państw rozwijających się, intensyfikacji współpracy w ramach procesu ASEM, dialogu miedzycywilizacyjnego itd.

\section{W kontaktach KPCh z partiami politycznymi różnej orientacji państw UE:}

W latach 50-70. partnerami tej partii były partie komunistyczne maoistowskie, lewackie i lewicowe socjalistyczne, w latach 80. - głównie partie orientacji prawicowej, związane z budową przeciwwagi dla ZSRR (,radzieckiego socjalimperializm”). Od połowy lat 90. ma miejsce niezwykle intensywna wymiana setek delegacji partii politycznych, grup parlamentarnych, regionalnych ugrupowań partii politycznych ze szczególnymi preferencjami dla partii socjaldemokratycznych i socjalistycznych.

Jest to niezwykle ważny czynnik poznawania doświadczeń socjaldemokratycznych w budowie modelu spolecznego państwa dobrobytu i na tej podstawie zaadaptowania ich do warunków chińskich oraz wypracowania rodzimych rozwiązań związanych z charakterem, kierunkiem i wyzwaniami transformacji w ChRL, charakterystycznych zmian w postawie chińskiego partnera. Szczególna w tym zasługa obecnej osobistości nr $1 \mathrm{w}$ ChRL - Hu Jintao. 


\section{W sferze gospodarczej}

\section{Wspótpraca handlowa:}

Po rozszerzeniu do 25 państw (1.V.2004) UE stała się pierwszym partnerem handlowym ChRL (w wypadku całych Chin, plus Hongkong, Makau i Tajwan, bez porównania większym), a Chiny drugim UE. W 2004 r. obroty wg danych chińskich wzrosły o 33,6\% w porównaniu z 2003 r. i przekroczyły zaplanowane na 2007 r. 150 mld USD osiagając 177,29 mld USD. W roku następnym wg danych chińskich osiągnęły: 217,3 mld przekraczając zaplanowany przez obie strony na $2013 \mathrm{r}$. poziom $200 \mathrm{mld}$ USD. (Dla porównania skali dokonanego skoku w okresie ostatnich 11 lat: w 1994 r. obroty 43,9 mld USD ( chiński eksport 16,25 mld, import 27,64 mld), w 2005 r.217 mld USD (chiński eksport:143,7 mld, import 73,6 mld. USD). Deficyt Chin w 1994 r. wyniósł: ponad 11 mld USD, a w 11 lat później (2005) ujemny bilans w obrotach tym razem przypadł na UE i wyniósł wg statystyk chińskich ponad 70 mld USD, wg unijnych - osiagnął poziom 127,3 mld USD (106,3 mld euro).

\section{Inwestycje bezpośrednie, transfer technologii, wspótpraca naukowo-techniczna:}

Według wstępnych danych inwestycje przekroczyły w końcu 2004 r. 40 mld USD (4 miejsce wśród inwestorów zagranicznych). UE jest największym dostawcą technologii i urządzeń do ChRL, w tym projektu nawigacji satelitarnej Galileo. Uruchomione zostały największe na świecie programy współpracy naukowo-technicznej (UE-China Framework Programme), szczególnie w takich dziedzinach jak biotechnologia, zdrowa żywność, nanotechnologia, energia, ochrona środowiska, medycyna (SARS), informatyka, atomistyka (Euroatom-China Research and Development) itd.

\section{W sferze kultury, oświaty, nauki, turystyki}

\section{W dziedzinie kultury:}

Chiny przystapiły na wielka skalę do ofensywnego wykorzystania osiagnięć swojej kultury i sztuki jako oręża promocji i zwiększenia swego międzynarodowego prestiżu. Europa jest centrum tych zabiegów. Po otwarciu swych centrów kulturalnych w Paryżu (2004) i Berlinie (2005) planują utworzenie ich w najbliższych latach w Brukseli, Londynie, Rzymie, Madrycie. W ChRL (w Pekinie, Szanghaju, Kantonie) istnieją Instytuty Kultury i ich filie Niemiec, Francji, Wielkiej Brytanii, Włoch. Wyrazem ożywienia kontaktów kulturalnych było ogłoszenie 2004 roku Rokiem Chin we Francji i Rokiem Francji w Chinach. Planowane są podobne imprezy na zasadach wzajemności z najważniejszymi państwami UE. 


\section{W dziedzinie turystyki:}

W październiku 2003 r. podpisano serię porozumień dotyczących wymiany turystycznej (Approved Destination Status Agrement). Szacuje się, iż zgodnie z tymi postanowieniami już w 2004 r. ponad 600 tys. turystów chińskich odwiedziło państwa UE. (Chińskie agencje turystyczne oferują 10-dniowy pobyt w Europie w cenie ok.10 tys. RMB, tj. ok.1.220 USD).

W roku akademickim 2003-2004 ok. 100 tys. chińskich studentów było zarejestrowanych na uczelniach wyższych UE (połowa w Wielkiej Brytanii). Restrykcje wizowe po 11 września 2001 r. wprowadzone w USA, wskazują, że „fala chińska” kieruje się stopniowo do Europy. Potwierdzają to wstępne dane roku akademickiego 2004-2005. Natomiast zaledwie ok. 5.000 europejskich studentów studiowało na wyższych uczelniach ChRL (z tego 1.280 z Niemiec); liczby te jednak rosną. UE gwarantowała w 2004 r. dodatkowo 250 stypendiów dla studentów i aspirantów w ramach programu Erasmus Mundus China Windows. Jesteśmy świadkami dynamicznego rozwoju kontaktów bezpośrednich i zacieśniania współpracy pomiędzy wyższymi uczelniami obu stron (głównie uniwersytetami). Strona chińska proponuje stworzenie stałego mechanizmu koordynacji współpracy w tej dziedzinie, wzajemne uznanie dyplomów i stopni naukowych, zwiększenie wymiany osobowej studentów i pracowników naukowych, wzmocnienie ośrodków nauki języków. Powstaje Chińsko-Europejska Międzynarodowa Szkoła Biznesu w Szanghaju.

\section{W dziedzinie wojskowej:}

Od czerwca 1989 r. stosunki te utrzymywane są na szczeblu narodowym a nie unijnym (głównie Francja, Wielka Brytania), m.in. w postaci wspólnych ograniczonych manewrów morskich w dziedzinie poszukiwań i ratownictwa morskiego. Brytyjczycy uczestniczą w programach szkoleniowych personelu wojskowego ChAL-W, zaangażowanego w misjach pokojowych, oficerowie chińscy są słuchaczami wyższych uczelni wojskowych w RFN, Francji i Wielkiej Brytanii, Utrzymuje się regularne kontakty Ministerstw Obrony Narodowej i Sztabów Generalnych, a także dowódców różnych rodzajów wojsk i służb. Zakupy sprzętu wojskowego i technologii „podwójnego zastosowania” nie objętych embargiem są niewielkie i tak w latach: 2001 - wynosiły 69 mln USD, 2002 - ok. 210 mln euro, w 2003 - 416 mln euro (544 mln USD); dotyczą głównie Francji, Włoch, Wielkiej Brytanii). Głównym dostawcą dla ChAL-W pozostaje od połowy lat 90 . XX w. Rosja: ok. 95\% importowanej broni i wyposażenia.

Trudno się zatem dziwić, że oceniając dynamizm rozwoju stosunków z UE kursuje w Pekinie zapożyczone z prasy unijnej określenie „chińskiej gorączki w Europie” (Ouzhou de Zhongguo re). Poprzedni przewodniczący Komisji Europejskiej, obecny premier Włoch - Romano Prodi, mówiąc z włoska swadą o relacjach pomiędzy Pekinem a Brukselą stwierdzał: „Jeśli nie jest to jeszcze związek małżeński, to na pewno bardzo, bardzo poważne zaangażowanie". Jego następca José Manuel Barroso dodawał: "Wierzę, iż istnieje obopólne zainteresowanie $\mathrm{z}$ obu stron rozwijania długofalowych strategicznych stosunków partnerstwa. Jestem pewny, iż następne 5-lecie przyniesie ogromny postęp w budowie takiego strategicznego partnerstwa”. Obie strony dość zgodnie określaja aktualny charakter swych relacji jako „strategiczne partnerstwo”. Różnice dotyczą stopnia 
jego zaawansowania, przy czym partner europejski - pomimo, że bardziej zaangażowany - ocenia je powściągliwiej.

\section{Przyczyny zmian w relacjach UE- Chiny w ostatnim 12-leciu}

Wybitny znawca problematyki chińskiej, prof. David Shambaugh, pisał, że „Chiny i UE cieszą się wydłużającym ,miodowym okresem” i wzajemnym wybuchem gorących uczuć po latach ,utrzymywania sporadycznych kontaktów i niewiele znaczących związków". Rodzi to naturalne pytanie: dlaczego?

Ze względu na bezlitośnie upływający czas, muszę się ograniczyć do hasłowego potraktowania odpowiedzi, ograniczając się do najważniejszych czynników

- Praktycznie do zakończenia zimnej wojny, (,jesieni ludów” 1989 w Europie Środkowo- Wschodniej, zjednoczenia Niemiec i rozpadu ZSRR) stosunki UE - Chiny w ogromnym stopniu kształtowane były przez bipolarny układ sił Waszyngton - Moskwa i ich obozy, dla obu więc stron kluczowe były relacje pomiędzy supermocarstwami.

- Zarówno w procesach integracji w Europie, jak i zainicjowanego w drugiej połowie 1978 r. przez Deng Xiaopinga procesu reform i otwarcia na świat (gaige kaifang), następowały fundamentalne zmiany.

- W rodzącym się postzimnowojennym porządku światowym, ze względu na pozycję i wagę obu partnerów oraz ich aspiracje - relacje pomiędzy Brukselą a Pekinem nabierały zarówno w ich relacjach wzajemnych jak i w układzie globalnym zasadniczego znaczenia.

- Czynnikami, które w istotnym stopniu sprzyjały zbliżeniu był fakt, iż UE w przeciwieństwie do Stanów Zjednoczonych - nie ma zasadniczych strategicznych i militarnych interesów w Azji, a w relacjach bilateralnych problem Tajwanu jest nieporównywalny do jego znaczenia $\mathrm{w}$ stosunkach chińsko-amerykańskich. Pamiętajmy, że obie te kwestie (Tajwanu i potencjalny konflikt interesów strategicznych), wiążące się wzajemnie, stanowią determinujący czynnik w relacjach USA-ChRL).

- UE i Chiny reprezentują zbliżone stanowiska wobec niektórych aspektów polityki zagranicznej i szeregu kwestii globalnych administracji G. W. Busha po 2001 r. Upraszczając - są zainteresowane (chociaż „nieco odmiennie”) ograniczeniem siły i dominacji amerykańskiej i jej unilateralizmem poprzez wzmocnienie roli ONZ i opowiadają się (także,,nieco odmiennie") za budową świata wielobiegunowego. Według ocen chińskich wspólnota „strategicznych interesów” Pekinu i Brukseli, które „łączą i będą łączyły jeszcze przez wiele lat” partnerów, wynika z niebezpieczeństw dla obu stron „płynących z nadmiernych ambicji Ameryki”, które stanowią "zagrożenie dla tradycyjnych i rodzących się mocarstw" (tj. UE i Chin). 
Nie oznacza to, iż którakolwiek ze stron jest zainteresowana budową antyamerykańskiego sojuszu, gdyż, jak wskazują Chińczycy: „nie ma obecnie na świecie państwa, które dążyłoby do konfrontacji z USA". Dla obu stron Stany Zjednoczone pozostają $\mathrm{w}$ istocie najważniejszym partnerem i interlokutorem. Dlatego Bruksela i Pekin będą rozwijały swoje stosunki z Waszyngtonem kierując się własnym interesem. I jeszcze jeden, w moim przekonaniu, najistotniejszy czynnik: szczególny charakter więzi interatlantyckich, oparty na wspólnocie wartości, więzi historycznych, fundamentalnych interesów strategicznych, stopniu wzajemnych powiązań itd., nieporównywalnych do żadnych innych układów „w pięciokącie”( USA, UE, Chiny, Rosja, Japonia).

- Następstwo konsekwentnych wysiłków obu stron preferujących zbliżenie. W moim przekonaniu to wynik przede wszystkim opracowania właściwych, opartych na strategicznej wizji i trafnym programie, działań praktycznych UE wobec Chin - zapoczątkowanych w latach 1994-95 oraz stopniowej, niepozbawionej zahamowań, adekwatnej reakcji władz ChRL (por. Biała Księgę o stosunkach z UE z października 2003).

- Rozmiary i komplementarność gospodarek UE i Chin.

- Zbliżeniu służą: pragmatyczne podejście, coraz solidniejsza baza gospodarcza oraz fakt, iż ,nie tylko nie dzielą je fundamentalne różnice geopolitycznych interesów, lecz w ostatnich latach obserwuje się zbliżenie właśnie na płaszczyźnie strategicznej i geopolitycznej".

- „Aspekt psychologiczny”. Chińczycy uważają iż łatwiej im porozumieć się z Europejczykami, gdyż narody tego kontynentu ,mają bogate tradycje ruchów lewicowych" i nie kierują się takimi uprzedzeniami prymitywnego antykomunizmu jak Amerykanie. „Czerwone Chiny” nigdy nie były traktowane w Europie jako zagrożenie typu radzieckiego.

\section{Chiny i UE sprzeczności i różnice}

Stara chińska maksyma głosi: ren he shi wu dou you qi langmian xing [każda rzecz ma swoje dwie strony]. Kilka słów, siłą rzeczy skrótowo, o różnicach, wzajemnych ansach i sprzecznościach pomiędzy Pekinem a Brukselą.

Główne zastrzeżenia ze strony Chin dot. polityki UE

1. Niekonsekwencje, wieloznaczność $\mathbf{i}$ naruszanie ustaleń $\mathbf{w}$ tajwańskiej polityce UE. Chodzi o postawę, którą partner chiński określa mianem: shuangzhong de liangmien xing - podejście o podwójnym obliczu. Zarzuty dotyczą różnic pomiędzy ustaleniami na szczeblu unijnym (wykluczające utrzymywanie oficjalnych kontaktów z przedstawicielami władz wyspy) a narodowym, na którym ta zasada jest często łamana poprzez kanał tzw. dyplomacji turystycznej, dostawy sprzętu wojskowego i technologii „podwójnego zastosowania” przedstawianej jako operacje czysto handlowe itd. 
2. Problem praw czlowieka - zaliczany przez chińskich partnerów do "sfery ideologicznej". Temat ten jest stale na wokandzie i nie będę go w tym miejscu szerzej omawiać. Chciałbym zwrócić jedynie uwagę na to, iż Chińczycy, zapewne nie bez czytelnych intencji, podkreślają różnice w podejściu Brukseli i Waszyngtonu, akcentują instrumentalny charakter postawy amerykańskiej i znacznie częstsze stosowanie $\mathrm{w}$ tej kwestii podwójnych standardów oraz wykorzystywanie jej $\mathrm{w}$ celach wywierania nacisku politycznego. Twierdzą, iż w wypadku amerykańskich partnerów łatwiej im się porozumieć $\mathrm{w}$ tej kwestii z administracjami republikańskimi niż demokratycznymi. Interesujące wydają mi się uwagi prezentowane „prywatnie" przez chińskich rozmówców. W prowadzonym dialogu w kwestii ochrony praw człowieka z UE, łatwiej im porozumieć się ,z doceniającymi wagę suwerenności państwowej politycznymi siłami prawicowymi, niż z partiami lewicowymi”. Ich zdaniem dużo mniej ortodoksyjnie podchodzą do tych kwestii duże państwa europejskie (bo bardziej potrzebują Chin), niż nieposiadające globalnych interesów małe państwa typu Dania, Holandia, Szwecja, czy Polska, które w tych kwestiach sprawiają im „najwięcej kłopotów”. W obu wypadkach jest to takie „nieoficjalnie oficjalne" stanowisko.

3. Wpływ polityki amerykańskiej na stosunki UE - Chiny uważają za zbyt duży i nierzadko sprzeczny z ich wzajemnymi interesami, za utrudniający porozumienie. Myślę, że ten temat też nie wymaga w tym gronie szerszego rozwinięcia.

4. Problem embargo na sprzedaż broni i sprzętu wojskowego, to jeden z najgłośniejszych, ale nie koniecznie w danym momencie najważniejszy „kamień obrazy". Chiny zarzucają europejskiemu partnerowi, iż taka postawa nie odpowiada stanowi i deklaracjom o charakterze wzajemnych stosunków, jest „,wyrazem mentalności zimnowojennej” i „ewidentnym anachronizmem” w obecnych relacjach wzajemnych. Problem ten oczywiście jest znacznie bardziej skomplikowany. Odnosi się to do przynajmniej pięciu aspektów:

a. Po pierwsze: $\mathrm{w}$ tej sprawie występują istotne różnice stanowisk 25 państw członkowskich, przy czym na pewno większość, chociaż nie wśród największych państw, zgłasza zasadnicze zastrzeżenia wobec takiej decyzji.

b. Po drugie: zachodzi konieczność rozwiązania tej kwestii w ramach wypracowania odnowionego, całościowego porozumienia dot. zasad regulacji kwestii eksportu broni i technologii defensywnych, porozumienia obowiązującego wszystkich członków UE. Porozumienie Code of Conduct z 1998 r. pozostawia możliwości rozciagliwej interpretacji jego ustaleń. Musi ono precyzyjnie określać kryteria oraz warunki, które musza być spełnione przez partnera.

c. Po trzecie: przestrzeganie praw człowieka nadal jest przedmiotem poważnego zaniepokojenia $\mathrm{w}$ wielu państwach UE, nawet jeśli nikt nie neguje postępu jakiego dokonano w tej dziedzinie w ChRL po $1989 \mathrm{r}$.

d. Po czwarte: problem ten ma poważne znaczenie w relacjach interatlantyckich ze względu na stanowisko Stanów Zjednoczonych, 
e. Po piqute: należy brać pod uwagę - a często zapomina się o tym - zastrzeżenia zgłaszane, przeważnie dyskrecjonalnie, przez niektórych bliższych i dalszych sąsiadów azjatyckich Chin. Wiąże się także z kwestią rozbudowywanego potencjału militarnego ChRL vis-a-vis Tajwanu i co za tym idzie równowagi sił w regionie Zachodniego Pacyfiku.

5. Odmowa uznania gospodarki ChRL jako gospodarki rynkowej. Ta decyzja przyjmowana jest szczególnie boleśnie przez stronę chińską, gdyż oceniana jest jako motywowana względami politycznymi i wiąże się z konkretnymi konsekwencjami gospodarczymi. Jako argument przytaczany jest fakt, iż status taki przyznano znacznie mniej zaawansowanej rynkowo Rosji. Odnośnie praktyk dumpingowych, Chińczycy, próbują tłumaczyć, że winne są rozbudowane systemy opieki społecznej w Europie, które wyśrubowując koszty robocizny powoduja, że towary europejskie w porównaniu z chińskimi są drogie i niekonkurencyjne. Partnerzy z EU odrzucają zarzuty o motywach politycznych ich postępowania, wskazują, ze strona chińska nie przestrzega zobowiązań, które wynikają z jej akcesu do WTO i porozumień z partnerami. Dotyczy to przede wszystkim sprawy dostępu do rynku, zniesienia sztucznych barier dla importu niektórych towarów (m.in. sposób kontroli cenowej, dyskryminacyjne zasady rejestracji, arbitralne standardy fito-sanitarne itd.), dalszej liberalizacji inwestycji, (zniesienie utrzymywanych administracyjnie ograniczeń geograficznych, sektorowych, branżowych dla cudzoziemców, dyskryminacyjnych zasad licencyjnych, wymiany itd.), poprawę warunków i klimatu dla biznesu, w których kwestia ochrony praw intelektualnych znalazła się na czele listy). UE oferuje program pomocy dla rozwiązania tych problemów.

Główne zastrzeżenia UE wobec Chin

Tu już naprawdę skrótowo, gdyż te sprawy są bardziej u nas znane, no i potrójna presja zmęczenia słuchaczy, pana przewodniczącego i czasu. Najważniejsze to:

1. Stan przestrzegania praw człowieka - przy uznaniu dokonanych postępów.

2. Ciągłe praktyki dumpingowe, skala piractwa (podróbek), budzący rosnące zaniepokojenie stan ochrony praw intelektualnych, omijanie uzgodnionych kwot (vide ostatnie spory dot. eksportu tekstyliów, obuwia, zabawek, niektórych produktów rolnych itd.) i rosnący lawinowo deficyt $\mathbf{w}$ obrotach handlu zagranicznego UE. Wg danych unijnych wyniósł on 66 mld USD w 2003 i 102,3 mld USD w 2004 r., z czego wynika, że w tym roku ujemny bilans handlowy z Chinami był o $20 \%$ wyższy niż cały deficyt handlowy z pozostałą częścią świata i stanowił 4\% wartości globalnych obrotów handlu zagranicznego Wspólnoty (w 2005 r. wyniósł on ok. 127 mld USD).

3. Pelne wprowadzenie przez ChRL zobowiązań wynikających $z$ akcesu do WTO.

4. Problemy nielegalnej emigracji, kłopoty z umową o readmisji.

5. Braku jednoznacznej deklaracji o zagwarantowaniu pokojowego procesu reunifikacji kraju (sprawa Tajwanu).

6. Niektóre problemy związane z Hongkongiem 
Generalnie jednak Pekin i Bruksela są zgodne, iż są to sprawy ważne, które jednak można będzie stopniowo rozwiązywać i są one wtórne do oczywistych fundamentalnych interesów i aspiracji obu partnerów, związanych z ich współpracą.

\section{Uwagi końcowe:}

Najważniejszymi przyczynami dla UE i Chin umacniania wzajemnych stosunków są względy strategiczne, geopolityczne i gospodarcze. Te czynniki oraz postępujący proces integracji i umocnienia UE (pomimo okresowych trudności i niepowodzeń) powoduje, iż żadne mocarstwo, w tym także Chiny, nie mogą ignorować faktu, iż UE jest globalnym czynnikiem na arenie światowej i coraz efektywniej realizuje wspólną europejska politykę zagraniczną i bezpieczeństwa (CFSP). Świadczy o tym ewolucja (i pragmatyczne korekty) w unijnej polityce Chin, w coraz większym stopniu uwzględniająca w praktyce ten fakt. Różnie to bywało poprzednio, dziś podobne elementy można dostrzec w polityce rosyjskiej.

Oczywiście nie należy ignorować faktu, iż obaj partnerzy mają niekiedy różne spojrzenia, wynikające m.in. $z$ odmiennego charakteru struktur i systemu podejmowania decyzji przez suwerenne unitarne państwo i strukturę międzynarodową (która wciąż jest w trakcie kształtowania się) oraz słabości rodzącej się CFSP, nie mówiąc o odmiennym zrozumieniu i priorytetach pojęcia bezpieczeństwa politycznego jak i wojskowego. Różne też jest spojrzenie na przyszłość partnera (dotyczące jego rozwoju, zagrożeń przede wszystkim związanych z wewnętrznym rozwojem, ale także i zewnętrznymi wyzwaniami oraz zdolności do stawienia im czoła). Np. dla Pekinu - jest to m.in. problem przyszłości integrującej się Europy, zdolności UE do zapewnienia gwarancji bezpieczeństwa, w tym militarnych. Dla Brukseli - m.in. rozmiar zagrożeń wewnętrznych w Chinach i sposób ich przełożenia, przynajmniej dziś traktowanych w kategoriach teoretycznych „chińskiego zagrożenia".

\section{Henryk Szlajfer}

Szereg kwestii, do których chciałem się odnieść, zostało już poruszonych - za co jestem wdzięczny moim przedmówcom. Zanim jednak przejdę do analizy niektórych spraw aktualnych, krótka uwaga dotycząca pewnych szerszych implikacji chińskiej modernizacji. Trwa ona od końca lat 70., czyli już niemal trzydzieści lat, a jest wciąż traktowana jako nowość, niespodzianka, a w każdym bądź razie jako zjawisko sprzeczne z niektórymi teoriami ekonomicznymi podejmującymi problematykę wzrostu. Odnoszę wrażenie, że wspomniane już w debacie pojęcie Washington consensus jest do pewnego stopnia traktowane jako poręczny instrument ,czarowania owiec” (w wolterowskim rozumieniu) czy odczyniania „złych duchów”. Wiele interesujących - i mniej interesujących - opinii wyrażono już na ten temat. Warto jednak mieć na uwadze, że John Williamson, który pod koniec lat 80 . ukuł ten termin (i koncepcje), ma, jak wynika z jego kolejnych publikacji, poważne problemy ze zrozumieniem, co też koncepcja Washington consensus 
miałaby oznaczać - w porównaniu z tym co rzeczywiście napisał. Ale to tylko na marginesie. Znacznie bardziej interesujące są szersze implikacje „wzrostu Azji”, w tym przede wszystkim Chin. W perspektywie porównawczej i historycznej - jeżeli pominiemy skalę zjawiska (liczące ponad miliard ludności Chiny) - sam proces wzrostu gospodarczego, jaki ma miejsce w Chinach, nie jest niczym nowym. Takie zjawisko, choć w mniejszej skali, w Azji już się pojawiło, czy też jest kontynuowane. Oczywiście, w przypadku Chin skala jest ogromna i to ona każe nam patrzeć w inny sposób na ten ogromny eksperyment. Natomiast sama „mechanika” tego wzrostu nie jest wielkim zaskoczeniem.

Warto również zwrócić uwagę na nowszą literaturę dotyczącą problemów politycznych czy sporów wokół doktryn wzrostu gospodarczego i historii gospodarczej już nie tylko Azji, ale również świata, jaka pojawiła się w związku z chińskim „cudem gospodarczym". Bardzo interesującym zjawiskiem, które pojawiło się jako produkt uboczny fenomenu modernizacji Chin ostatnich trzydziestu paru lat, jest próba zasadniczej rewizji historii gospodarczej nie tylko ostatnich dwóch, trzech stuleci lecz całej nowożytności. Historia współczesnych Chin - i całej Azji - jest coraz częściej czytana niejako wstecz, reinterpretowana jako polemika z eurocentryzmem (prace J. Pomeranza, A. G. Franka i in.). To, co my nazywamy wyjątkowością europejską czy unikalnością europejskiego rozwoju ostatnich dwóch-trzech stuleci - mam na myśli cud rewolucji przemysłowej - jest dzisiaj czytane w całkiem inny sposób. Jest to uboczne, ale bardzo ważne zjawisko związane z tym, co dzieje od trzydziestu lat w Chinach.

Przechodzę do sprawy Chin jako państwa-mocarstwa i sposobu ich postrzegania i definiowania m.in. przez Stany Zjednoczone.

Po pierwsze, chciałbym zasugerować, aby analizując Chiny jako państwo i już de facto mocarstwo, nie traktować ich - co pojawia się nadal w niektórych tekstach sino- czy azjocentrycznych - nadal w kategoriach państwa postkolonialnego, jedynie walczącego o przetrwanie, takiego pussycat, „,biednego, niewinnego kotka”. Państwo to nigdy nie było - pominąwszy długie stulecie „hańby” poprzedzające rok 1949 - „niewinnym kotkiem”. I zwłaszcza dzisiaj nie jest takim „kotkiem” na arenie międzynarodowej.

Druga sprawa. Państwo to działa w rejonie, który z punktu widzenia kształtowania porządku międzynarodowego jest obszarem niezwykle słabo zinstytucjonalizowanym. Jeśli porównać poziom instytucjonalizacji stosunków międzynarodowych w Europie czy na obszarze euroatlantyckim $\mathrm{z}$ tym, jaki mamy do czynienia w Azji, w rejonie działania i oddziaływania Chin, Azja jest regionem, który dopiero znajduje się w trakcie poszukiwania swojej formuły instytucjonalizacji. Tu poczyniono dopiero pierwsze kroki w kierunku „miękkiej” instytucjonalizacji stosunków międzynarodowych i porządku międzynarodowego. W sferze bezpieczeństwa nie są to nawet pierwsze kroki. Należy to mieć na uwadze analizując międzynarodowe zachowania Chin.

Trzecia sprawa. Nie ma, jak sądzę, powodu, aby wątpić, że priorytety chińskie w polityce zewnętrznej są dzisiaj w sposób bardzo wyraźny podporządkowane wymogom polityki wewnętrznej, w szczególności kontynuacji polityki wzrostu gospodarczego. Jednocześnie wydaje się, że jest to państwo - dotyczy to w szczególności elity władzy - już dostatecznie silne i elastyczne w swoich zachowaniach, aby dawać sygnały, że do tego jego rola nie będzie się ograniczać. Mówiąc to, mam na myśli zarówno rzeczy dobre, 
jak i złe. Do rzeczy dobrych należy z pewnością aktywne zaangażowanie Chin w proces sześciostronnych negocjacji dotyczących potencjału nuklearnego Korei Północnej. Uczestnictwo tego państwa w tym procesie i, dodam, bardzo interesująca i pozytywna rola Pekinu, jest nie do przecenienia. $\mathrm{Z}$ drugiej strony trudno ignorować działania, choćby z końca lat 70., niejako „porządkujące” otoczenie Chin. „Przywołanie do porządku" Wietnamu, czy raczej próba takiego działania, było sygnałem, że, zdaniem Pekinu, pewien hierarchiczny „porządek” w otoczeniu Chin powinien zostać zaprowadzony. Ta lekcja, jak sądzę, nie została zapomniana w regionie. Podobnie jak ostatnio wspólne chińsko-rosyjskie manewry wojskowe. Nota bene, jest pewnego rodzaju paradoksem - ale nie zaskoczeniem - gwałtowne ocieplenie stosunków między Stanami Zjednoczonymi a zjednoczonym Wietnamem. Nie odbywa się ono, jako żywo, na wspólnej bazie ideologicznej. Odbywa się natomiast m.in. właśnie z uwagi na „pomruki”, jakie od czasu do czasu wydaje wielkie państwo chińskie.

Wiąże się z tym trzecia kwestia. Wspomniałem już o Korei Północnej. O ile można i należy odnotować pozytywną rolę Pekinu w sprawie negocjacji dotyczących potencjału nuklearnego KRLD, nie jest $\mathrm{z}$ kolei jasne stanowisko Chin, jeśli chodzi o zjednoczenie Korei. Nie zostało ono zdefiniowane. Sądzę, że nie będzie ono w najbliższych latach zdefiniowane do końca z bardzo prostego względu. Można mianowicie przypuszczać, że zjednoczenie obu Korei - zwłaszcza jeżeli jego rezultatem byłoby wyraźne gospodarcze (i polityczne) wzmocnienie obu części - nie byłoby widziane w kierownictwie chińskim, przynajmniej dzisiaj, jako zjawisko w stu procentach pozytywne.

Czwarta kwestia, o której jeszcze w trakcie debaty nie wspomnieliśmy. Proces przyspieszonej modernizacji osłabia - a nie utwierdza - wizerunek Chin, zwłaszcza w relacjach ze Stanami Zjednoczonymi, jako wroga ideologicznego. Definicje sprzed $1989 \mathrm{r}$. straciły na aktualności, mimo trwania autorytarnego systemu podtrzymującego komunistyczne symbole. Oznacza to, że konkurencja i ewentualne konflikty pojawiają się na innej płaszczyźnie. Należy w związku z tym zadawać pytania dotyczące czynników wywierających wpływ na kształt polityki wewnętrznej i zewnętrznej Chin. Czym ideologia komunistyczna została zastapiona? Co jest dzisiaj czynnikiem spajającym politycznie i ideologicznie społeczeństwo chińskie? Przyspieszony wzrost gospodarczy jest z pewnością czynnikiem sprzyjającym utrzymaniu względnej zwartości społeczeństwa chińskiego. Nie jest jednak czynnikiem jedynym. Wydaje mi się, że ci eksperci od spraw chińskich, którzy powiadają że wzrasta niepomiernie rola nacjonalizmu, mają rację. Jeśli tak rzeczywiście jest, to znając dynamikę napędzającą nacjonalizm jako czynnik legitymizujący system polityczny i system gospodarczy, można żywić pewne obawy w jaki sposób ów nacjonalizm się wyrazi jutro i w dalszej przyszłości. Na znamy, jak do tej pory, przypadku nacjonalizmu, zwłaszcza w wykonaniu mocarstwa - a takim sa Chiny - który ograniczałby się do porządkowania tylko i wyłącznie sceny wewnętrznej. Stąd otwarta kwestia, raczej spekulacja aniżeli prognoza, w jakim kierunku następować będzie ewolucja systemów, znaków ideologicznych, które legitymizują system chiński. Jest to jedna z zasadniczych kwestii. Jej właściwe zrozumienie (i odczytanie związanych $\mathrm{z}$ nią implikacji) jest niezbędne w formułowaniu prognozy dotyczącej zmian w Chinach i w ich otoczeniu. 
Piąta kwestia dotyczy pewnych symboli związanych ze sposobem myślenia zarówno partnerów Chin, jak i samej elity chińskiej. Mam tu na myśli sprawę embarga. Sprawa ta jeszcze kilka miesięcy temu była niezwykle gwałtownie dyskutowana. Nie chodzi tu o tekstylia, zabawki, czy tanie komputery, nie o demolowanie - w oczach nacjonalistycznie nastawionych przywódców związkowych w wielu krajach europejskich - rynku pracy w Europie. Chodzi o embargo dotyczące broni, jako symbolu odzyskiwania przez Chiny „niezależności” i „wybijania się” na mocarstwo. Spór ten wydaje się do pewnego stopnia trywialny, natomiast fakt, że ta właśnie płaszczyzna sporu została wybrana, jest niepokojący. Wybór płaszczyzny, która nie wiąże się ani z utrzymaniem poziomu wzrostu gospodarczego Chin, ani z rozwiązywaniem problemów społecznych, ani nawet z kwestią, czy Chiny są zagrożone, czy też nie - bo nie są dzisiaj zagrożone - związanej natomiast ściśle z osiaganiem tradycyjnie definiowanego statusu mocarstwa, jest niebezpieczny. Dodam jednak natychmiast, że pozytywnym faktem jest to, że w ostatnich paru miesiącach temperatura sporów wokół tej kwestii obniżyła się i, być może, znalazła się ona na pewien czas tam gdzie powinna, czyli gdzieś w aneksie do innych ważniejszych sporów.

I ostatnia sprawa, o której chciałbym tylko krótko wspomnieć. Dzisiaj nie można jeszcze mówić, że mamy do czynienia z ugruntowaną, mającą wymiar strategiczny, polityką amerykańską traktowania Chin jako - jak to określił będąc w Chinach R. Zoellick, pierwszy zastępca sekretarz stanu C. Rice - „odpowiedzialnego udziałowca” (a respectable shareholder) w spółce, która nazywa się porządek światowy. Deklaracja taka jest, jak sądzę, próbą, ale dopiero próbą. Jest wyrażeniem jeszcze nie skonkretyzowanej nadziei, a nie stwierdzeniem faktu. Zbyt wiele jest jeszcze starych i nowych punktów zapalnych wokół Chin (lub związanych z Chinami). Mogą one sprawić, że nadzieja ta pozostanie jeszcze przez pewien czas rzeczywiście pobożnym życzeniem. Nie implikuje to jednak poglądu, że Chiny są dzisiaj głównym czynnikiem konfliktogennym, powodującym wzrost napięcia w regionie. Względna stabilność jest nadal w interesie Chin. Ta bowiem warunkuje kontynuację procesu modernizacji.

\section{Krzysztof Gawlikowski}

Jeśli państwo pozwolą to, jako pierwszy dyskutant, chciałbym do tej szerokiej palety zagadnień politycznych i gospodarczych, dodać jeszcze jeden wątek: przemian w sferze kultury i poczucia tożsamości. W tej sferze także następują bardzo doniosłe przemiany.

Pamiętacie państwo doskonale, że na początku lat 90. pojawił się problem wartości azjatyckich. Wylansował tę koncepcję Mahathir bin Mohammad, premier Malezji, jednego z najbardziej demokratycznych krajów muzułmańskich (chociaż jest to tzw. „demokracja konsocjonalna” oparta na zabezpieczaniu praw trzech grup etnicznych tam mieszkających). Malezja - to zarazem państwo prawa, a system ten wprowadzili tam jeszcze Brytyjczycy w czasach kolonialnych. Nie jest to wcale zjawisko powszechne w tym rejonie. Drugim współtwórcą tej koncepcji był Lee Kuan Yew, budowniczy nowoczesnego Singapuru i jego wieloletni premier. Obecnie bardzo szanowana osobistość w całym „świecie chińskim”. Singapur - to z kolei kraj swoistej „sterowanej demokracji”, a można by nawet powiedzieć: „utopii konfucjańskiej”, prawicowego (a nie lewicowego - jak 
w Skandynawii), bardzo skutecznego państwa opiekuńczego, także opartego na ścisłym przestrzeganiu prawa. Jest to jedyne współczesne państwo, które organizuje życie społeczno-polityczne zgodnie z zasadami konfucjańskimi, i wychowuje młodzież w tym duchu, a osiagnęło zarazem zadziwiające sukcesy gospodarcze. Obydwaj ci politycy, wcale nie pałający sympatią do siebie, już poprzednio byli krytykowani w zachodnich kręgach liberalnych za odstępstwa systemów politycznych w ich krajach od modelowych demokracji liberalnych Zachodu, chociaż kraje sąsiednie, gdzie częstokroć prawa człowieka były łamane dużo jaskrawiej, traktowano zwykle dużo życzliwiej. Koncepcje „wartości azjatyckich" ściagnęły jednak na nich prawdziwe gromy.

W największym skrócie można powiedzieć, iż politycy ci wskazywali na odmienności kulturowe Azji od świata zachodniego i bronili utrzymywania tych tradycji kulturowych. Podkreślali oni, iż w Azji ceni się przede wszystkim „właściwy porządek społeczny" i harmonię społeczną, szanuje się też wszelkie władze. Prymat przyznaje się tam interesom społeczeństwa i rodziny, i na tej ostatniej - jako podmiocie zbiorowym - opiera ład społeczny, a odrzuca nadmierny, ich zdaniem, indywidualizm zachodni. W ujęciu singapurskim nacisk też kładziono na powinności jednostki wobec siebie samej, rodziny i państwa, nie zaś na jej swobody, potrzebę ekspresji itp.

Premier Mahathir powoływał się przy tym na badania porównawcze Azji Wschodniej i Stanów Zjednoczonych przeprowadzone przez Davida I. Hitchcocka (Center of International and Strategic Studies, Washington DC). Wykazują one jasno, że „właściwie zorganizowane społeczeństwo” (orderly society) zostało wybrane jako wartość przez 71\% Azjatów, a tylko 11\% Amerykanów (zapewne inaczej też pojęcie to rozumieli!); „utrzymanie harmonii społecznej” wybrało 58\% Azjatów i tylko 7\% Amerykanów. Natomiast ,swoboda samowyrażania się jednostki” była ważna tylko dla 47\% Azjatów, ale aż 85\% Amerykanów; swobody jednostki wybrało tylko 32\% Azjatów i aż 82\% Amerykanów; podobnie ,„prawa jednostki” wybrało jedynie 29\% Azjatów i 78\% Amerykanów. Szacunek dla władz uznało za wartość 42\% Azjatów i 11\% Amerykanów. Bardzo ciekawe było określenie sposobu podejmowania decyzji politycznych. Za otwartą debatą publiczną kontrowersyjnego problemu było 29\% Azjatów i 74\% Amerykanów, natomiast za decyzjami podejmowanymi droga prywatnych konsultacji, za ,zamkniętymi drzwiami” przez upoważnione do tego osoby, było też 29\% Azjatów, ale żaden Amerykanin nie wybrał tej opcji. Troszczenie się przede wszystkim o siebie preferowało tylko 10\% Azjatów i aż 59\% Amerykanów. Jak widać, odmienne preferencje w sferze wartości nie są wymysłem niektórych polityków azjatyckich, lecz rzeczywistością, która trzeba uwzględniać. Rzutuje to nawet na sferę stosunków międzynarodowych, w których kraje Azji Wschodniej preferują także osiaganie konsensu i szanowanie partnerów, a nie „domaganie się swego” przez jedną ze stron, czy narzucanie swych racji. Podobnie też, jako obraźliwe, traktują one publiczne oskarżenia i potępienia jakiegoś kraju, gdyż za właściwe przyjmują konfidencjonalne negocjacje i działania krok po kroku.

Sprawa „wartości azjatyckich” jest oczywiście o wiele bardziej skomplikowana niż obydwaj ci politycy ją przedstawiali. Trudno też mówić o wspólnych wartościach przyjmowanych przez muzułmanów, buddystów, konfucjanistów i katolików (z Filipin), mimo pewnych podobnych preferencji. Mogę polecić lekturę przekładu przemówienia 
programowego premiera Mahathira w Waszyngtonie i omówienia jego koncepcji przez polskich specjalistów w 2 tomie „Azji - Pacyfiku”, a także książkę pod redakcją Adama Jelonka: Wietnamczycy, systemy wartości - stereotypy Zachodu (Scholar 2004), gdzie opublikowano przekład wspomnianego studium Hitchcocka i zaprezentowano pogłębione polskie badania polowe wartości współcześnie przyjmowanych przez młodzież wietnamską.

Wobec ogromnych nieporozumień i częstego u nas opisywania koncepcji wartości azjatyckich bardzo tendencyjnie, czy nawet w sposób fałszywy, chciałbym przypomnieć kluczowe tezy Mahathira. Mówił on nie tylko, iż wartości zachodnie i azjatyckie się różnią, ale także podkreślał, że wartości azjatyckie przyjmowane nawet współcześnie są zbieżne $\mathrm{w}$ dużym stopniu $\mathrm{z}$ tzw. wartościami wiktoriańskimi uznawanymi dawniej w Europie. Jego zdaniem Zachód obecnie zagubił te wartości, ale nadal są one szeroko przyjmowane nie tylko w Azji, ale także w Ameryce Łacińskiej i Afryce. Bronił prawa Azjatów do zachowywania swoich standardów moralnych i uznawania za naczelne rodzin i wspólnot, a potępiał narzucanie siłą Azjatom współczesnych wartości zachodnich, zwłaszcza amerykańskich, indywidualistycznych i hedonistycznych, jako destrukcyjnych dla społeczeństwa i tożsamości kulturowej krajów azjatyckich. W podtekście jego wystąpień zawarty był gorący apel: "pozwólcie nam układać życie po swojemu, tak jak my nie narzucamy wam naszych norm i zwyczajów".

W swoim programowym przemówieniu w Waszyngtonie w 1996 r., Mahathir nie tylko przedstawiał różnice kulturowe z omówionych powyżej badań Hitchcocka, ale także stwierdził:

$\mathrm{Na}$ Zachodzie jest wiele osób szczerze i głęboko przekonanych, że ich system wartości jest uniwersalny, że jest on ceniony i podzielany przez wszystkich cywilizowanych ludzi na calym świecie [...]. Wielu ludzi na Zachodzie również szczerze wierzy, iż obrońcy i szermierze wartości azjatyckich, czy też innych wartości, najzwyczajniej usprawiedliwiaja przemoc, rzady dyktatorskie oraz inne formy niecywilizowanego postępowania [...].

Tak się składa, że ja wierzę $w$ istnienie wielkiego obszaru wspólnych wartości, które wszyscy podzielamy, co wynika po prostu z faktu, ze wszyscy jesteśmy ludźmi [...]. Zarazem jednak wierzę, że istniejq naturalne różnice $w$ wartościach. Ci, którzy twierdza, że ich nie ma, sa jak daltoniści [...].

Przez stulecia bardzo wielu z nas, w Azji, wierzyto, że nasze azjatyckie wartości i sposoby działania sq ,nizsze”. Jeśli dzisiaj Azjaci odkrywaja, że te wartości i sposoby działania nie sq gorsze tylko dlatego, że sq azjatyckie, a często sq nawet wręcz lepsze, mimo tego, że sq azjatyckie, to mam nadzieję, ze można będzie nam to wybaczyć. Szczególnie wtedy, gdy codziennie czytamy o rzeczach strasznych, które - wedle relacji samych ludzi Zachodu tam się dzieja, jak też o wielu wspaniałych, które - jak znowu oni sami stwierdzaja - dzieja się na Wschodzie [...].

Mam nadzieję, że moja prezentacja wartości azjatyckich w najmniejszym stopniu, jak do tej pory, nie była usprawiedliwieniem dyktatury, autorytaryzmu, praktyk antydemokratycznych, tamania praw człowieka, czy odrzucania demokracji. Mam nadzieje, że moje rozważania również $w$ żaden sposób nie usprawiedliwiaja stosowania tortur, 
wykorzystywania pracy dzieci, ucisku kobiet, czy nieodpowiedzialnego niszczenia środowiska naturalnego.

Bardzo znamienne zakończenie wspomnianego przemówienia Mahathira przytoczę w całości, ponieważ jest ważne:

Stynny politolog, Samuel Huntington, kończy swoja równie sławna prace ,,Zderzenie cywilizacji”, mało stuchanym apelem do cywilizacji, by ze sobq wspótistniały. Ja ze wszystkich sit, jakie posiadam, nawoluję nie do wspótistnienia, ale do wzajemnego kulturowego wzbogacania się.

My w Azji, nauczyliśmy się bardzo wiele od Zachodu. Bylibyśmy zmuszeni do zupetnie niepotrzebnego ograniczania petni naszego potencjatu, gdyby ten proces miat teraz zostać zatrzymany. Jednocześnie tu, w Azji, mamy wiele do uczenia się również od „,Wschodu”, to jest od innych krajów Azji [Mahathir postulował zwłaszcza uczenie się od Japończyków - KG], jak też od Afryki, Ameryki Lacińskiej, a ponadto wszystkiego tego co najlepsze ma nam do zaoferowania nasza własna historia i kultura.

Jestem przekonany, że Ameryka Pótnocna, również może uznać za wartościowe, do pewnego stopnia, to wezwanie do wzbogacania się nawzajem, do wzajemnego wzbogacania się, odmładzania i samoodkrywania.

Azjatyckie wartości pozostaja wartościami azjatyckimi, a amerykańskie - amerykańskimi. Jednak te bliźnięta moga się spotkać [nawiązywał tu do R. Kiplinga, który pisał o Wschodzie i Zachodzie jako o bliźniętach, „które nie mogą się spotkać”, to jest poznać - KG]. Z takiego spotkania może zrodzić się pewne zrozumienie i docenienie madrości każdej ze stron, a nawet szczesśliwe połaczenie tego, co maja dobrego, a odrzucenie tego, co jest złe, czy wrogie.

Niechaj każdy z nas przyzna, że nikt nie ma monopolu na madrość. Przygotujmy się świadomie do „uczty wydanej przez cywilizacje” $i$ weźmy z zapatem $w$ niej udzial, aby każdy z nas mógt otrzymać to, co najlepsze z tego, co wszyscy możemy zaoferować, dla zbudowania wspólnie, po raz pierwszy, jednej globalnej cywilizacji jakiej jeszcze świat nie widzial ${ }^{1}$.

Jak widać, trudno tu znaleźć grzechy, jakie się zazwyczaj przypisuje na Zachodzie koncepcji „wartości azjatyckich”, potępionych chyba głównie dlatego, że odrzucały one bezwzględny prymat Zachodu we wszystkich dziedzinach i konieczność kopiowania jego rozwiązań - jako uniwersalnych i nowoczesnych - we wszystkich dziedzinach. Niezadowolenie budziła zwłaszcza krytyka współczesnych zasad liberalnych, w tym przypisywanie kluczowego znaczenia swobodom i prawom jednostki, głęboko zakorzenionym w tradycjach Zachodu, ale sprzecznych z tradycjami azjatyckimi. Oburzenie Mahathira i jego kolegów budził nie tylko brak szacunku dla partnerów azjatyckich, ich tradycji i dziedzictwa, ze strony wielu intelektualistów i polityków Zachodu, lecz także

1 Patrz: Mahathir bin Mohamad, Rozważania o wartościach azjatyckich, „Azja-Pacyfik” 1999 t. 2, 157-168. Przemówienie to wygłosił na XXIX Międzynarodowym Zebraniu Rady Gospodarczej Basenu Pacyfiku, 21 maja 1996 r. w Waszyngtonie (tekst ten upowszechniał MSZ Malezji jako dokument państwowy). Podobne tezy prezentował ten polityk także w innych swoich publikacjach. Patrz np. jego książka: A New Deal for Asia, Palenduk Publications, Subang Jaya 1999, 67-80. 
brak chęci zrozumienia innych cywilizacji i kultur, przy etnocentrycznym uważaniu swego dorobku zachodniego za uniwersalny i obowiązkowy dla wszystkich.

Prawdopodobnie ze względu na to wrogie przyjęcie koncepcji wartości azjatyckich przez Zachód, większość krajów Azji Wschodniej zdystansowała się od nich, chociaż w praktyce często przyjmowano poglądy podobne. Np. w Chinach największą popularność w latach 90. XX w. zdobyła koncepcja „fuzji cywilizacji”, tj. syntezy wszystkiego, co najlepsze z cywilizacji chińskiej (czy też szerzej - Azji Wschodniej) i wszystkiego, co najlepsze, z zachodniej. Głoszono zarazem, że taka synteza stanie się podstawą rodzącej się nowej cywilizacji światowej. Nie dodawano, że w takim przypadku czołową rolę odegra w tym Azja Wschodnia, a szczególnie Chiny, choć implicite to było zawarte. W praktyce kładziono tam jednak głównie nacisk na szybkie przyswajanie sobie przez Chiny dorobku Zachodu - jako zadanie najpilniejsze dla rozwoju i modernizacji kraju. Natomiast wzbogacanie przez Zachód swej cywilizacji dorobkiem azjatyckim, przede wszystkim w sferze „kultury społecznej”, której w opinii Azjatów bardzo tam niedostaje, pozostawiano samym mieszkańcom Zachodu, którzy powinni o to się postarać dla własnego dobra. (W tomie 5 rocznika „Azja - Pacyfik” omawiamy rezultaty badań opinii chińskich na ten temat).

Próby przewartościowania naiwnych postaw apologetycznego zachwytu Zachodem i fascynacji jego naśladowaniem, i odradzanie się zainteresowań tradycjami rodzimymi, widać było w latach 90. XX w. nawet w najbardziej pro-amerykańskiej Japonii. Można tu przytoczyć, np. poglądy Shintaro Ishihary, jednego z czołowych działaczy orientacji nacjonalistycznej. Tekst, który tu zacytuję, opublikował on w 1995 r., czyli jeszcze przed wygranymi wyborami na burmistrza Tokio. Przypominam, że startował on jako kandydat niezależny i dwukrotnie wygrał te wybory. Nie był to zatem jakiś działacz z głębokiej prowincji, burmistrz zacofanego miasteczka, lecz burmistrz wielkiej metropolii, który pokonał kandydatów wspieranych przez partie. A zdobył on sławę książką Japonia może powiedzieć NIE, gdzie potępiał mentalność wiecznego przytakiwania Stanom Zjednoczonym i twierdził, że Japonia nie powinna się zachowywać jak kolejny stan Stanów Zjednoczonych. Pisał on następująco o dotychczasowych doświadczeniach japońskich:

Przez ponad sto lat Japończycy pilnie przyswajali sobie owoce cywilizacji zachodniej i tak byli tym pochlonięci, że zapomnieli, że sq Azjatami. Byliśmy tak pracowitymi uczniami [Zachodu - KG], że osiagnęliśmy sukcesy na wielu polach [...], ale nasze serca pozostały $w$ dużym stopniu azjatyckie [...].

Zachodni pracownicy myśla, że zaprzedaja swa dusze swej kompanii, aby zdobyć chleb codzienny, natomiast Azjaci traktuja wykonywanie swej pracy jako akt wdzięczności wobec bogów i Buddy za błogosławieństwo życia. Dla nas uczciwe wykonywanie swego zawodu jest świętym obowiqzkiem, ale powiedz to Europejczykowi, a będzie on myślat: „To jest absurdalne" [...] Podsumowujqc, podstawowe sposoby myślenia - światopoglad, który formuje jednostkę i spoleczeństwo - na Wschodzie sq inne niz na Zachodzie. To zaś, że ludzie Zachodu krytykuja nasz styl życia, bo po prostu nie jest on taki jak ich - jest oburzajace. 
...bieg historii znowu powraca do Azji. Region pozostajacy w tyle przez dwa stulecia prześcigną dzisiaj Zachód gospodarczo i zbliża się do prześcignięcia Zachodu także $w$ aspekcie cywilizacyjnym. Tak jak Azjaci byli inspirowani przez zachodni modernizm, Europa i Ameryka Pótnocna będa znowu zwracać się ku Wschodowi po madrość. Nie ma przecież nic wstydliwego w poszukiwaniu wyższej kultury [...].

Jestem pewien, że era Azji będzie okresem pokojowego wspótistnienia. Nie stanowimy bowiem zagrożenia dla Europy, czy Ameryki Pótnocnej. Nie będziemy przecież robić im tego, co Zachód robił nam. Inaczej niż kolonialni panowie, którzy starali się nawrócić miejscowe ludy na chrześcijaństwo; bez względu na to, jak Azja byłaby potężna, nigdy nie będziemy narzucać innym naszych wierzeń. To nie nasz sposób działania [...].

Wielu ludzi Zachodu postępuje tak, jakby prawa człowieka stanowily ich moralny przywilej, ale jest tak tylko do chwili, kiedy przypomni się im ich wlasne kompromitujace czyny w Azji, a wtedy ich pretensje upadaja jak domek z kart. Jednakże wskazywanie na ich hipokryzję nie powstrzymuje Amerykanów [od krytykowania Azjatów - KG]. Wciaż oskarżajq oni azjatyckie rzqdy o rzekome tamanie tych praw, o politykę antyzwiazkowa, czy rzekome niedemokratyczne praktyki [...].

Popatrzmy jednak, co gloryfikacja praw jednostki przyniosta społeczeństwom zachodnim. Ludzie maja swobodę odrzucania Boga, a nawet samej wolności i popetniania przesteepstw ... ${ }^{2}$.

Fantastyczny rozwój gospodarczy Azji Wschodniej, przyswojenie sobie tam zachodniej cywilizacji naukowo-technicznej oraz industrialnej - zmieniają dzisiaj, zwłaszcza w erze globalizacji, relacje tego regionu z Zachodem. Kraje cywilizacji wschodniazjatyckich stały się przecież pierwszymi i dotychczas jedynymi przedstawicielami cywilizacji nie-zachodnich, którzy już dorównali Zachodowi (jak Japonia i Hongkong), czy dopiero z powodzeniem starają go doścignąć (jak Korea Południowa, Tajwan, ChRL i inne kraje regionu).

Obecnie, po fazie zafascynowania naśladowaniem Zachodu, Azjaci nie tylko sami zwracają się do rodzimych tradycji, ale i żądają od Zachodu poszanowania ich wyborów oraz kultur. Doświadczenia Japonii, Korei Południowej, Hongkongu, czy Singapuru pokazują dobitnie, że cywilizacja przemysłowa może występować w rozmaitych wariantach kulturowych, podobnie jak demokracja, choć dyskusje nad jej różnymi kulturowymi modelami są dopiero w powijakach. Roger T. Ames i David L. Hall ze Stanów Zjednoczonych twierdzą np., że na gruncie konfucjańskich tradycji rozwijać się może z powodzeniem ,demokracja komunikacyjna”, lansowana niegdyś w Ameryce, choć bez powodzenia, przez Johna Deweya. Preferował on demokracją komunitarnego typu, nie zaś liberalną. Hahm Chaibong z Korei Południowej twierdzi z kolei, że w jego kraju formuje się stopniowo „demokracja personalistyczna”, oparta na więziach społecznych jednostki, nie zaś indywidualistyczna, jaka zdobyła dominację na Zachodzie³.

2 Mahathir Mohamad, Shintaro Ishihara, The Voice of Asia: Two Leaders Discuss the Coming Century, Kodansha Int., Tokyo-New York, 1999 (pierwsze wydanie 1995), s. 89-100.

3 Patrz ich studia zawarte w zbiorze: Confucianism for the Modern World, pod red. Daniela A. Bella i Hahma Chaibonga, Cambridge University Press, Cambridge 2003. 
Można przypomnieć, że nie tylko młodzi Azjaci, którzy przybywając na Zachód na studia, czy w poszukiwaniu pracy, są często zaszokowani i przerażeni jego „degradacją moralną", egoizmem, osamotnieniem jednostki, itp. Na samym Zachodzie też coraz częściej pojawiają się głębokie krytyki dotychczasowych tendencji rozwojowych. Jednym z najwybitniejszych autorytetów krytykujących je fundamentalnie był nasz sławny rodak Jan Paweł II, wprawdzie u nas czczony, ale rzadko słuchany. Bardzo dobrze rozumiałby się z Mahathirem, gdyż głosił $\mathrm{w}$ istocie poglądy zbliżone, choć ze strony zachodniej, i wzywał nas do powrotu do wartości chrześcijańskich.

Wbrew temu, co sadzą zazwyczaj nasi zachodni intelektualiści i politycy, Azjaci generalnie wcale nie pragną zaprowadzania u siebie „porządków zachodnich”, wręcz przeciwnie: chcieliby przed nimi chronić swoje kraje, choć zarazem pragną ich rozwoju i modernizacji, ale przy zachowaniu własnych tradycji. W sumie dosyć to bliskie hasłu Marii Janion o Polsce: ,idźmy do Unii, ale z naszymi trumnami”! Azjaci też chcą dołączyć się do nowoczesnego świata, ale bez wyrzekania własnych wartości i tradycji. Oczywiście, są też w Azji fanatycy jej okcydentalizacji, ale są tam oni marginesem, jak w Polsce nasi buddyści, czciciele Hare Krishna i inni miłośnicy Wschodu. Chociaż to z nimi spotykają się głównie rozmaici przedstawiciele Zachodu i to spośród nich rekrutuje się wielu emigrantów azjatyckich na Zachód.

Dodać warto, że chociaż na Zachodzie wciąż dużymi wpływami cieszą się koncepcje narzucania wszystkim krajom świata, w tym i azjatyckim, naszych, zachodnich modeli polityczno-społecznych, wartości i mód, pod koniec XX w. nawet sam Francis Fukuyama zwątpił w realność szybkiego przyjęcia przez cały świat ukochanych przezeń liberalnych wzorców anglosaskich. Wezwania Samuela P. Huntingtona do rezygnacji z tego narzucania $\mathrm{i}$ do pogodzenia się $\mathrm{z}$ istnieniem innych cywilizacji i kultur odmiennych od zachodnich, nie zdobyły jednak szerszego uznania. A rozumiano jego tezy nieraz w sposób wypaczony, jako wieszczenie nieuchronnego - rzekomo - „zderzenia cywilizacji”, potwierdzonego jakoby przez atak terrorystów na Stany Zjednoczone w $2001 \mathrm{r}$. Zapominano zaś, że to miało grozić - zdaniem Huntingtona - właśnie w przypadku narzucania przez Zachód, zwłaszcza przez USA, swoich wzorców innym cywilizacjom.

Jak wiadomo, prezydent George W. Bush puścił te jego ostrzeżenia mimo uszu i zaplątał swój kraj w bezsensowną wojnę, rzekomo by zaprowadzić, choćby siłą, demokrację amerykańskiego stylu $\mathrm{w}$ świecie muzułmańskim. I poglądy podobne, żądające choćby sankcji wobec „nieposłusznych państw”, nie chcących naśladować wzorców zachodnich, nie były wcale odosobnione. Jednak pod koniec lat 90 . XX w. potępienia na Zachodzie zwolenników rodzimych tradycji w krajach azjatyckich - wyraźnie słabły. Trzeba się bowiem było godzić z realiami. Cichły też dyskusje o „wartościach azjatyckich". W 1998 r. w ONZ i w jego agendach - jak UNESCO, wypracowano nową koncepcję: „dialogu między cywilizacjami i kulturami”. Do jej wylansowania przyczynił się wyraźnie Iran.

W 2003 r. w Pekinie, na spotkaniu ministrów kultury ASEM, czyli forum dialogu między Unią Europejską a Azją Wschodnią, przyjęto zasadę, że ich stosunki wzajemne opierać się będą właśnie na zasadach dialogu między cywilizacjami. Chiny stały się jednym $\mathrm{z}$ aktywnych promotorów tej koncepcji w świecie, a popierały ją bardzo liczne kraje. 
Być może także dlatego, że była ona dość mglista, ale z pewnością wykluczała dyktat Zachodu i narzucanie jego koncepcji kulturowych.

Wspomnieć można, że wielu działaczy i badaczy sądzi, że zadziwiające sukcesy Azji Wschodniej w obecnym rozwoju gospodarczym opierają się na tradycjach konfucjańskich, i dlatego kraje, gdzie one kwitly, tak przodują. Nie twierdzę, iż opinie takie są słuszne, gdyż sprawy są o wiele bardziej złożone, ale koncepcje takie zdobywają niewątpliwie uznanie społeczne. Do tego dziedzictwa często nawiązuje się w Azji współcześnie. Dotyczy to także Chin, gdzie dyskredytacja komunizmu i rozwój gospodarki kapitalistycznej spowodowały swoistą pustkę duchową. Wypełniają ją w znacznym stopniu idee narodowe $\mathrm{w}$ nowym wydaniu, łączące się często $\mathrm{z}$ apoteozą konfucjanizmu, od wielu dziesięcioleci drogiego tamtejszym nacjonalistom, a obecnie oferującemu także etykę życia publicznego i indywidualnego, stosunkowo łatwą do przyswojenia, bo rodzimą.

Owo odradzanie się konfucjanizmu w Chinach jest zjawiskiem wieloaspektowym i spektakularnym. Patronują temu wprawdzie władze, ale tendencje takie są też żywe społecznie, a zainspirowali je $\mathrm{w}$ istocie intelektualiści chińscy $\mathrm{z}$ brytyjskiego jeszcze Hongkongu, z Tajwanu i Stanów Zjednoczonych. Znaczną rolę inspirującą odegrał też Singapur. W rezultacie, w 2004 r. w Qufu, ojczystej miejscowości Konfucjusza, gdzie nadal żyje jego klan i od tysiącleci oddawano cześć temu mędrcowi, po raz pierwszy od utworzenia ChRL złożono mu uroczyste ofiary z udziałem oficjalnych przedstawicieli państwa. Pojawiły się szkoły prywatne uczące konfucjanizmu, na wzór południowo-koreańskich. Wprowadzać zaczęto także zajęcia z konfucjanizmu na uczelniach wyższych, również najpierw w prywatnych. Nauka konfucjanizmu i studia prostszych tekstów konfucjańskich pojawiły się na zajęciach pozalekcyjnych w szkołach podstawowych i średnich. Już wcześniej moralność konfucjańska, choć bez odwoływania się do jej twórcy, pojawiała się w programach szkół podstawowych jako swoisty „duch narodowy”. Rozliczne popularne opracowania tekstów konfucjańskich wydają niezliczone wydawnictwa prywatne, co też poświadcza, ze jest na nie zapotrzebowanie. Zakończono niedawno kosztowną rozbudowę, w dużym stopniu ze środków prywatnych, kompleksu świątyń u grobu Cesarza Żółtego - mitycznego twórcy państwa chińskiego, a coraz liczniejsze rzecze Chińczyków z kraju i zagranicy udają się tam ze swoistą ,patriotyczną pielgrzymką”, co jest zjawiskiem nowym. Buduje się podobne, nawet zupełnie nowe, mauzolea innych postaci legendarnych. Zagranicą Chiny popierają tworzenie tzw. instytutów Konfucjusza dla propagowania kultury chińskiej i języka chińskiego.

Z jednej strony Chiny, i szerzej cała Azja Wschodnia, ulegają gwałtownej okcydentalizacji, a zwłaszcza amerykanizacji. Globalizacja i wzrost gospodarczy ogromnie te procesy przyspieszają. $Z$ drugiej zaś umacniają się tożsamości narodowe, poszukuje się tradycji rodzimych i odbudowuje się je świadomie. Umacniają się szybko ideologie narodowe. W tej sferze także następują zatem doniosłe i dramatyczne przemiany o konsekwencjach trudnych do przewidzenia. Awans gospodarczy i polityczny Chin, które stają się wraz z całym regionem głównym partnerem Zachodu, zmieniają w sposób nieunikniony cywilizacyjną panoramę świata.

Dziękuję bardzo i zapraszam państwa do dyskusji. 


\section{Witold Kieżun}

Jedną z metod badań socjologicznych i organizacyjnych jest obserwacja uczestnicząca. $Z$ ciekawością przyszedłem na tę konferencję, tak się bowiem złożyło, że w moim długim życiu miałem szereg okazji kontaktowania się z Chińczykami, a nawet prowadziłem działalność, w której pełniłem, w pewnym sensie, rolę nadzorczą - koordynacyjną w stosunku do dużego zespołu Chińczyków.

Przede wszystkim chcę podzielić się moimi doświadczeniami amerykańskimi i kanadyjskimi, gdzie stale miałem studentów Chińczyków. Byli to Chińczycy z Tajwanu, a w Kanadzie pojawili się Chińczycy już z ,komunistycznych Chin”. Dla mnie było to specjalnie interesujące ponieważ prowadziłem w czasie swojej pracy w Kanadzie, Stanach Zjednoczonych i innych krajach analizę oceny moich studentów według grup etnicznych, otrzymanych stopni, inteligencji i innowacyjności wykazywanej w czasie rozwiązywania problemów „,case studies”. Pamiętam, jak w uczelniach w Stanach Zjednoczonych z przerażeniem pytano: ,ilu masz Chińczyków?” Ja mówię: „,siedmiu”. „O rany! Siedmiu!”

Dlaczego? Dlatego, że Chińczycy - to się absolutnie sprawdziło - byli niesłychanie staranni w nauce, powiedziałbym wręcz zachłanni na wiedzę i bardzo wymagający w stosunku do wykładowcy.

Pamiętam taki przykład z Filadelfii. Jednym z kryteriów amerykańskiego systemu anonimowej oceny profesorów przez słuchaczy jest „dostępność profesora,” mierzona w skali od zera do 10. Kiedyś, o godzinie 10 wieczorem, dzwoni do mnie mój chiński student i mówi: „Panie profesorze, mam jutro przedstawić swoją pracę, ale mam pewne wątpliwości, które chciałbym z panem skonsultować. Czy mogę do pana przyjechać?" Myślę sobie: nie mogę mu odmówić, bo jeśli odmówię, to będzie znaczyło, że nie jestem dla studentów dostępny. Mówię więc, „OK., mój adres jest ....”. On na to: „Ojej, to jest akurat po drugiej stronie Filadelfii! Ale mam pewną propozycję - ponieważ nasza uczelnia znajduje się w centrum, w połowie drogi między Pana a moim miejscem zamieszkania, spotkajmy się tam”. Byłem już w piżamie, ale myślę sobie: Boże kochany, odmówię? Mam przecież siedmiu Chińczyków - wszyscy lojalnie postawią mi zero. Będę spalony, nie będę mieć szans na przedłużenie kontraktu. Więc mówię: „dobrze, będę tam za 3 kwadranse”. „OK. - odpowiada student - ja będę tam za pół godziny i będę na Pana czekał." Przyjeżdżam, on już był na miejscu. Prawdopodobnie Państwo wiecie, że w USA czołowe uniwersytety i ich biblioteki są otwarte przez 24 godziny. Efekt - półtorej godziny rozmowy ze mną. „A może to... A może by mi Pan wskazał jakieś inne pozycje bibliograficzne... itd.”. Szczęśliwie miałem tam swoją podręczną bibliotekę, wziął 3 czy 4 książki.

W Kanadzie Chińczycy specjalnie bili się o celującą ocenę A+. Było tradycją, że na jednym kursie można było wystawić tylko jedną ocenę $\mathrm{A}+$. Ambitniejsi studenci, w ich liczbie z reguły wszyscy Chińczycy, starali się ją za wszelką cenę uzyskać. Dlaczego? Bo w Stanach Zjednoczonych i Kanadzie, jeśli ktoś kończy studia i przedstawia swój dyplom pracodawcy, to on mówi mu - „dyplom to za mało, daj mi wykaz wszystkich swoich stopni, z całego okresu studiów. Jeśli miałeś dobre stopnie, to dam ci więcej”. Podobnie oceniani byli u siebie Chińczycy z Tajwanu i Chin komunistycznych. 
Pamiętam pewną studentkę żydowskiego pochodzenia, której rodzice wyemigrowali z Polski już po wojnie. Urodziła się w Kanadzie, ale biegle mówiła po polsku. Przychodzi do mnie i pyta: ,jakie ja mam szanse na A+ ?" A bardzo jej na tym zależało, bo rodzice postawili warunek: „z podstawowego przedmiotu „Teoria Zarządzania” musisz mieć A+, jeśli nie dostaniesz takiej noty, nie będziemy dalej finansować twoich studiów". Mówi dalej: ,ja chyba nie mam szans, bo - cóż - ja mogę pracować 8 godzin, ale Chińczycy i inni Azjaci pracują po 10-12 godzin. Nie dam rady, bo mam jeszcze inne zainteresowania...". Radzę jej: „Poczekaj...Teraz jest pierwsza część zajęć, wykłady monograficzne, ale potem będą ćwiczenia, cases. Studenci będą musieli rozwiązywać pewne problemy, a więc wykazać się innowacyjnością, kreatywnością, umiejętnością analizy itp. Zobaczymy jak wtedy sobie dadzą radę". Przy case'ach Chińczycy wysiadali. Ambitna Żydówka biła ich na głowę inteligencją, kreatywną łatwością wyszukiwania wariantów rozwiązań. A więc u moich chińskich studentów jedynie pracowitość była ich atutem. Ale poeta mówi: ,talenta ma wielu, praca tworzy geniuszy”.

Moje następne kontakty z Chińczykami miały miejsce w Burundi, małym kraju w Centralnej Afryce. Kierowałem tam ONZ-owskim programem modernizacji kraju i jego metod zarządzania. Rząd Chin w ramach akcji pomocy dla Trzeciego Świata zobowiązał się do budowy jednej autostrady około $120 \mathrm{~km}$ długości. Przyjechało 300 Chińczyków z kierownictwem i tłumaczami. Zbudowali na przedmieściu stołecznej Bujumbury obóz z małymi domkami, ogrodzony płotem, z jedną tylko bramą wjazdową. Byli zupełnie odizolowani, do miasta mogli wychodzić tylko w grupach minimum trzyosobowych. Zorganizowali pracę $\mathrm{w}$ przedziale 10-godzinnym, od 8 do 6 wieczorem, $\mathrm{z}$ dwugodzinną przerwą, ale na terenie pracy, bez powrotu do obozu. W miarę postępu budowy niektóre zespoły lokowały się dalej od miasta. Przewidzieli pracę przez 7 dni w tygodniu. Interweniowałem w tej sprawie u kierownika. Odpowiedział: „To są odgórne założenia, zresztą oni bardzo chca pracować cały tydzień inaczej nie mieliby pełnej satysfakcji z dobrze wykonanej pracy.” Zawiadomiłem centralę ONZ w Nowym Jorku o fakcie łamania podstawowego prawa do maksymalnie 48-godzinnego tygodnia pracy. Nowy Jork odpowiedział: „Nie zajmuj się tym. To jest ich sprawa. Ostatecznie to oni finansuja..”

Rozmawiałem też w tej sprawie z ich lekarzem, specjalistą od akupunktury, który mówił po angielsku. Wyjaśniał mi: „,my jesteśmy genetycznie zupełnie inni, niż wy. Nas stworzyła filozofia konfucjańska, a Konfucjusz właśnie kładł nacisk na bardzo sprawną pracę. Cała filozofia konfucjanizmu to jest sprawna praca, podporządkowanie się w rodzinie, w państwie, w zakładzie pracy, spokój, akceptacja istniejącej sytuacji, ugodowość. Mało tego, my kochamy pracę. Dla nas praca jest sama w sobie satysfakcją. A więc stąd nasz stosunek do pracy - praca się autonomizuje jako najwyższa wartość". Muszę powiedzieć, że nie zdawałem sobie z tego sprawy.

W tej chwili w Stanach Zjednoczonych ludzie też coraz dłużej pracują, ale po to żeby więcej zarobić. Stale się biją o podwyżki. Wiemy, co się dzieje w Europie, we Francji, w Niemczech. Tam stale strajkują, bo chcą mieć więcej wolnego czasu i więcej zarabiać. Postulaty 48-godzinnego i 46-godzinnego tygodnia pracy. Ale jak temu Chińczykowi o tym powiedziałem, zaśmiał się: „48-godzinny tydzień? Niemożliwe. Zobaczysz, że u nas będą się bić, żeby czas pracy nie został skrócony. Wy nas nie rozumiecie". 
I tu jest odpowiedź na to pytanie, które postawił pan profesor. Niesamowity rozwój Chin jest funkcją paru czynników. Pierwszy, to świadomość konfucjańskiej tradycji i właśnie w tej chwili widać próbę jawnego powrotu do niej - bo ona była ukryta, ale istniała w świadomości. Jednak genetyka 2300 lat swoje robi. A dodajmy, że reżim komunistyczny też pobudzał do współzawodnictwa pracy.

Występuje tu swoista analogia do okresu żywiołowego rozwoju protestanckiej Ameryki, która z biednego kraju w drugiej połowie XIX w. urosła do pierwszej potęgi przemysłowej świata. Ideologiczną podstawą była kalwińska wiara, że bogactwo jest błogosławieństwem bożym udzielanym tym, którzy pracują uczciwie i wydajnie.

I jeszcze jedna sprawa dotycząca wewnętrznej dysharmonii środowiska chińskiego. Jak się zorientowałem moi studenci byli podzieleni na subgrupy etniczne, nie mówiąc już o zupełnej separacji poszczególnych grup: tajwańczyków, komunistów, emigrantów mieszkających w Kanadzie.

Dalszym znanym mi problemem chińskim jest nielegalne osiedlanie się na Syberii. Informował mnie niedawno o tej sprawie jeden z profesorów rosyjskich odwiedzających naszą uczelnię. Jak twierdził, średnio około 4 tysięcy Chińczyków codziennie przekracza granicę rosyjską i osiedla się na Syberii, i nic w tej sprawie nie da się zrobić. „Przepłacają władze graniczne i osiedlają się. My jesteśmy zupełnie bezsilni”. Mówię, „dobrze, no i co dalej?” „No cóż..... może za 30, 40 lat, może później i Syberia będzie chińska”.

Dziękuję serdecznie. Wystapienia referentów były niesłychanie interesujące i wiążą się z moimi indywidualnymi obserwacjami.

\section{Maria Wągrowska.}

Dołączając się do opinii o walorach wystapień, chciałabym zadać pytania. Czy w dialogu amerykańsko-chińskim jest mowa o Rosji i Japonii, a jeżeli tak, to w jakich kontekstach i z jaką intensywnością obie strony na te tematy rozmawiają. Czy można prosić o scharakteryzowanie głównych tendencji w chińskiej polityce względem Azji Centralnej?

\section{Władysław Góralski}

$\mathrm{Na}$ wstępie chciałbym wyrazić uznanie dla organizatorów dzisiejszego spotkania za podjęcie tematu, który jest przedmiotem naszych obrad, mianowicie: Chiny - Unia Europejska - Stany Zjednoczone. Rozumiem takie ujęcie sprawy, chociaż wydaje mi się, że prezentacja tematu była, w pewnym sensie, trochę ograniczona. Chodziło pewnie o wyeksponowanie roli Chin i zgadzam się z taką koniecznością, gdyż te szybko rozwijające się Chiny są słabo znane w Polsce. Przykładów tego mamy wiele. W grudniu 2005 r. słyszałem w telewizji komentarz na temat spotkania prezydenta Stanów Zjednoczonych i Chin podczas szczytu APEC. Powiedziano tam, że przywódcy obu krajów mają trudne sprawy do omówienia, między innymi deficyt amerykański, który w 2005 roku wynieść może jeden miliard dolarów. Nie wiedziałem czy się roześmiać czy się rozpłakać, że na tym szczeblu można takie błędne informacje podawać. Dzisiaj profesor Haliżak wspomniał ile ten deficyt wynosił. 
Ze względu na brak czasu chciałbym ograniczyć się do krótkiego przedstawienia trzech spraw. Pierwsze to jest coś, co wiąże się bezpośrednio z Chinami i dotyczy budowy, jeśli tak można powiedzieć, regionu Azji Wschodniej. No cóż, ten region istnieje i obejmuje poza Chinami trzynaście większych i mniejszych państw, niektóre są to państwa znaczne, jak na przykład Indonezja - ponad dwieście milionów mieszkańców i dwa miliony kilometrów kwadratowych. Niektóre z nich szybko rozwijają się. Szczególnie Wietnam, również Malezja i Tajlandia. W ostatnich latach dochód wytworzony w państwach regionu Azji Wschodniej kształtował się na poziomie 26\% dochodu światowego. Na tym poziomie, mniej więcej, utrzymywał się udział w handlu światowym ${ }^{4}$. Wspominano tu, że jeśli chodzi o Chiny, trudno powiedzieć czy ich statystyki są dokładne, czy też „mierzone na oko”. Otóż w handlu zagranicznym statystki są dosyć dokładne, bo jeżeli jedno państwo sprzedaje, to inne kupuje, więc wiadomo, o jakie pieniądze tutaj chodzi. A obroty są olbrzymie i rosną z roku na rok. W rozważaniach tych nie należy również pomijać Japonii. Kilkanaście lat temu Japonia była cytowana jako pierwszy kraj dynamicznie rozwijający się, przeżywający swojego rodzaju cud gospodarczy. W ostatnich latach ten rozwój spowolniał. Ale musimy sobie zdawać sprawę, że nawet 1,3\% wzrostu dochodu narodowego oznacza wzrost o około 5 mld dolarów - jest to suma olbrzymia. Dzięki tej pozycji krajów w regionie mają one oczywiście aspiracje do odgrywania odpowiedniej, większej roli we współczesnym świecie. I wszystko wskazuje, że tendencja do umacniania tego regionu ma wszelkie widoki na powodzenie.

Druga sprawa dotyczy zagrożeń. Wspomniano już o zagrożeniach wynikających z wyczerpywania się źródeł surowców nieodnawialnych; można tu jeszcze dodać sprawę powietrza i układu z Kioto, który nie jest realizowany. Są to oczywiście zagrożenia realne, ale - powiedziałbym - jednostkowe. Największym zagrożeniem w rozwoju współczesnego świata wydaje się być globalizacja oparta o złe zasady. Globalizacja jest zjawiskiem nieuchronnym, wiąże się ona $\mathrm{z}$ rozwojem cywilizacji. W tej chwili odbywa się ona na takiej zasadzie, że pomaga bogatym stawać się bogatszymi, a biedni stają się biedniejszymi. Bank Światowy prowadzi w swoich publikacjach, np. w „World Bank Atlas”, rubrykę gdzie pokazuje corocznie liczbę krajów i ludności o najniższym dochodzie, średnim dochodzie, średnio-wyższym dochodzie i najwyższym dochodzie. Otóż w tych rubrykach zwiększają się liczby dotyczące krajów ubogich, o niskim dochodzie narodowym i zwiększają się liczby krajów o najwyższym dochodzie. Nie chcę tutaj podawać szczegółowych liczb na ten temat, ale w tej chwili kształtują się one mniej więcej w ten sposób, że na $80 \%$ ludności świata przypada około $20 \%$ wytwarzanych dóbr. I odwrotnie - na $20 \%$ ludności przypada $80 \%$ dóbr. Tutaj konieczne jest wprowadzenie odpowiednich mechanizmów. To jest sprawa ekonomistów, ale nie tylko ekonomistów. Wprowadzenie odpowiednich mechanizmów, gdzie wyzysk uprawiany przez wysoko rozwinięte kraje mógłby być łagodzony i zmniejszony, leży także zresztą w interesie samych tych krajów. Już w tej chwili widać rzesze ludzi, którzy z „,biednych” obszarów uciekają. To już nie setki tysięcy, ale miliony, które uciekają szukając dla siebie w krajach rozwiniętych lepszego miejsca pod słońcem.

\footnotetext{
4 W 2004 r. wynosił on $29 \%$ w eksporcie i $23 \%$ w imporcie.
} 
Jeszcze kilka słów na temat biegunów. Oczywiście, odkąd znamy historię świata, historię cywilizacji wiemy, że zawsze występowało jakieś jedno wielkie mocarstwo - ale bywało też, że więcej niż jedno. Po drugiej wojnie światowej mięliśmy dwa bieguny Stany Zjednoczone ze swym zapleczem i Związek Radziecki. W ostatnich latach, oczywiście, dominującą rolę w stosunkach międzynarodowych odgrywają Stany Zjednoczone. Ale rosną i pozycje innych - tutaj wskazano oczywiście słusznie na Chiny, a ja poszerzyłbym ten obszar: na Chiny wraz z Azją Wschodnią. Na ten temat są różne przewidywania. Obok takich prognoz, że umocnią się dwa bieguny, to znaczy Stany Zjednoczone i Chiny, istnieją również przewidywania, że mogą być trzy bieguny, choć nie tak wyraźne: Stany Zjednoczone, Europa Zachodnia i Chiny z Azją Wschodnią. Osobiście te drugie wydają mi się bardziej realistyczne - nie wydaje mi się, żeby Europę można skreślić w tej sytuacji „na straty”. W Europie jest wiele potencjału, który może dynamizować rozwój, choć trudno powiedzieć, w jakich procentach. Może być ona jednym z biegunów wywierających wpływ na stosunki międzynarodowe.

Na zakończenie chcę powiedzieć uwagę, do której wracam przy wszystkich takich spotkaniach. To, co się dzieje poza Polską - a w tej chwili szczególnie nowe zjawiska na Dalekim Wschodzie, w Chinach i szerzej w Azji Wschodniej - powinniśmy znać i analizować, gdyż, pośrednio czy bezpośrednio, dotyczy również nas. Znajomość realiów kształtujących się na tych obszarach jest w Polsce słaba. Co prawda, występują tutaj pewne zmiany na lepsze i sytuacja się nieco poprawia, ale wydaje mi się, że potrzebnych jest nam znacznie więcej świadomych działań, zmierzających do poszerzania wiedzy o realiach w tej części świata, przy pomocy publikacji, szkolnictwa i innych środków.

\section{Kazimierz Krzysztofek}

Jest tu pewien problem, mianowicie problem produktywności Chińczyków i jednocześnie rodzącego się modelu konsumpcji. Profesor Piasecki mówił, a nawet straszył tym, że jeśli kiedyś miałaby się rozwinąć konsumpcja na poziomie średnich wskaźników zachodnich, to planeta tego nie wytrzyma. Otóż, zadaję sobie pytanie, czy w związku z tym, że Chińczycy czerpią z własnych zasobów, jeśli chodzi o produktywność, to czy będą czerpali z zasobów obcych, z modelu zachodniego, jeśli chodzi o konsumpcję? Tu jest pewne rozdarcie. Można powiedzieć, że dla swego rozwoju będą czerpać $\mathrm{z}$ tego, co można nazwać ex oriente lux, a jeśli chodzi o konsumpcję, to ex occidente luxus, czyli jest tu jakieś pęknięcie.

A co z tą tożsamością, jak wygląda relacja „nowoczesność - tożsamość”, czy może ta konsumpcja pójdzie u nich w innym kierunku, czy da się ekstrapolować doświadczenie Japonii? Japonia jednak jest krajem konsumpcyjnym, ale jakoś sobie z tym radzi, np. z ilością samochodów. Jest to kraj zmotoryzowany, chociaż jeśli wziąć skalę ponad 1 miliarda ludzi to skala chińska jest inna niż japońska, 10-krotnie większa w liczbach bezwzględnych. Tu jest pewna niespójność - chodzi o kulturę chińską, na ile ona filtruje z jednej strony wytwórczość, a z drugiej strony konsumpcję. Druga sprawa, o której wspomniał pan Piasecki - chodzi o self sustainability. Czy Chińczycy nie eksploatują rabunkowo swoich zasobów? A kolonizacja wsi? Taka modernizacja jest bardzo antyagrarna. 
Co będzie, jeśli im się te zasoby taniej siły roboczej wyczerpią i proste rezerwy skończą? Czy stać ich będzie na kreatywność bez indywidualizacji? Czy nie będzie to wymagać zmiany mentalnej, żeby mogli być twórczy, tak jak ludzie na Zachodzie? Bo na razie się okazuja zdolnymi imitatorami, tak jak Japończycy. I to jest właściwie generalny problem, na który sobie nie umiem odpowiedzieć, bo nie jestem tu zresztą specjalista. Indusi wydają się być bardziej nastawieni na ten samopodtrzymujący się rozwój i wykorzystują jednak bardziej własne zasoby intelektualne. Nie wiem, dlaczego. Czy może dlatego, że mają tradycję demokracji, a ta tradycja wyzwala twórczość, ponieważ indywidualizuje myślenie i nie jest to już tylko kultura perfekcji ale również kultura innowacji.

\section{Kazimierz Starzyk}

Pragnę nawiązać do jednego z wątków, który przewijał się we wszystkich znakomitych prezentacjach, jakie przedstawili nam dzisiaj paneliści, a mianowicie do dynamiki gospodarki chińskiej. Podzielając generalnie stanowisko referentów w kwestii dynamicznego wzrostu gospodarki ChRL, pragnę jednak sformułować tezę, że w średnim okresie możemy oczekiwać spadku tempa wzrostu PKB. Nie jest to teza w pełni oryginalna, gdyż jak wiadomo, nawet władze chińskie przewidują wyhamowanie tej dynamiki. Spadek istotnie może wynikać ze względów bilansowych - co właśnie Chińczycy podkreślają - co oznacza, że będzie czegoś brakować, np. energii elektrycznej, czy też niektórych surowców, co w konsekwencji może wpłynąć ograniczająco na tempo wzrostu PKB. Ale też istnieją inne przyczyny, które pozwolę sobie określić jako związane z elastycznym podejściem władz chińskich do strategii rozwojowej gospodarki chińskiej. Własne spojrzenie na tę kwestię przedstawię krótko w sześciu punktach.

Pierwszy, to problem wyboru, przed którym stoją chińskie władze - czy dalej zarządzać gospodarką na zasadzie władzy autorytarnej czy też demokratyzować system zarządzania, uwzględniając pluralizm polityczny jako polityczne źródło zarządzania gospodarką. A więc - autorytaryzm versus demokracja. Moim zdaniem, szersze wprowadzenie elementów demokratycznych w ChRL może być czynnikiem pośrednio wpływającym negatywnie na tempo wzrostu PKB. Krótkie uzasadnienie: casus Indii jest tu dobrym przykładem. Dlaczego Chinom wychodzi, a nie zawsze Indiom? Dzisiejsza poranna informacja, że Indie w 2006 roku osiagną kolejny raz wysoką roczną stopę wzrostu nie zmienia mojej powyższej refleksji. Istota sprawy polega bowiem na tym, że w Indiach, kraju w pełni demokratycznym, premier Manmohan Singh, chcąc realizować swój prorozwojowy program reform musi uzyskać na to aprobatę parlamentu. W warunkach istotnej roli jaką w tym parlamencie odgrywają partie lewicowe, często oznacza to wystapienie poważnych barier do wprowadzania reform prorynkowych, preferujących w pierwszej kolejności podwyższanie efektywności gospodarowania w miejsce postulowanych przez partie lewicowe celów społecznych, a to przecież nie jest możliwe w warunkach niedoborów gospodarki Indii.

Spójrzmy na Chiny, które wykorzystując doświadczenia Japonii oraz nowo uprzemysłowionych gospodarek Azji Wschodniej, zwłaszcza pierwszej generacji (tj. tzw. tygrysów azjatyckich: Hongkong, Tajwan, Korea Płd. i Singapur), na pierwszym 
miejscu postawiły na efektywność gospodarowania - wiążąc ją ze wzrostem PKB, postępem technicznym, równowagą wewnętrzną, równowagą zewnętrzną, wzrostem konkurencyjności, a dopiero wtórnie z dobrobytem. To właśnie realizacja takiej strategii jest jednym z kluczowych czynników, który Chinom pozwolił uzyskać wysoką pozycję w gospodarce światowej. Ale tutaj powstaje dylemat, czy preferować podwyższanie efektywności gospodarowania, tak jak uczyniły to Chiny, czy też uginając się pod presją społeczną, dążyć do rozwiązywania problemów społecznych, które często są sprowadzone do postulatu sprawiedliwości społecznej. Pierwsze podejście, preferujące efektywność gospodarowania rodzi szereg problemów. Przede wszystkim, pogłębia różnice w poziomie dochodu narodowego na głowę mieszkańca. Ale to nie wyczerpuje sprawy. Następuje bowiem także pogłębienie różnic $\mathrm{w}$ aspekcie regionalnym: Chiny Wschodnie, Chiny Zachodnie. Kolejny problem, to starzenie się ludności, jako rezultat poprawy poziomu życia. Ten problem dotyka dzisiaj Chiny, podobnie jak Stany Zjednoczone, Japonię czy kraje Europy Zachodniej. Stanowi to poważne obciążenie dla gospodarki.

Kolejna kwestia, to stopniowe odchodzenie od planów gospodarczych na rzecz programów. W Chinach, najpierw Komitet Centralny zatwierdza generalne kierunki rozwoju gospodarki na plenum w październiku i wybrane informacje przekazuje społeczeństwu. Następnie w trybie poufnym toczone są prace nad takim kształtem planu, który w marcu następnego roku zatwierdza Ogólnochińskie Zgromadzenie Przedstawicieli Ludowych (parlament). Wówczas następuje kompleksowe przedstawienie kierunku, w jakim gospodarka chińska będzie się rozwijać; w tym przypadku chodzi o lata 2006 -2010. I tutaj jest pewien bardzo istotny nowy element. Dotychczas jednoznacznie mówiło się: plan. Tym razem równolegle używa się pojęcia - program. A to w praktyce oznacza pełne przejście na mechanizm rynkowy.

Czwarta kwestia, która zresztą została tutaj bardzo ciekawie naświetlona przez pana profesora Haliżaka, to stosunki Chin ze Stanami Zjednoczonymi. Ze swej strony chciałbym zwrócić uwagę na dwie kwestie. Po pierwsze, na problem chińskiego eksportu na rynek amerykański. Rzeczywiście Amerykanie cieszą się, że towary chińskie są tanie, ale ta sprawa jest bardziej skomplikowana. Że się cieszą - to już zostało przedstawione w swoim czasie przez Alana Greenspana, byłego szefa FED (Banku Rezerw Federalnych USA), który posłużył się kiedyś tym argumentem, co potem było na różne strony powielane. Sprawa ma jednak dwa dodatkowe aspekty: pierwszy, że eksport chiński do Stanów Zjednoczonych jest w dużym stopniu eksportem ,amerykańskim”, ze względu na kapitał amerykański zainwestowany na chińskim rynku. Ale jest też drugi z tym związany, niezwykle istotny aspekt - to problem konkurencyjności tego eksportu. Jest on nadmiernie konkurencyjny z powodu kursu yuana. $\mathrm{O}$ to cała wojna się obecnie toczy i będzie toczyć aż do pełnego upłynnienia yuana. Rewaluacja dokonana w lipcu 2005 r. (około 3\%), potem skorygowana we wrześniu (do około 5\%) - to jest za mało w myśl oczekiwań amerykańskiego rynku. Tak więc widzimy tutaj pewien dualizm. Kiedy chodzi o interesy amerykańskich przedsiębiorców zaangażowanych na chińskim rynku, Chiny postrzegane sąjako partner. Z drugiej strony, jako konkurent - kiedy chodzi o chiński eksport na rynek amerykański, który ze względu na niedowartościowany kurs yuana prowadzi do nieuzasadnionego wzrostu jego konkurencyjności tym samym powiększając jego rozmiary do 
poziomu zagrażającego równowadze zewnętrznej gospodarki amerykańskiej. Co ciekawe, administracja podtrzymuje pogląd, że Chiny to strategiczny partner, ale już Senat jest pod tym względem podzielony. W Senacie jest więcej zwolenników traktowania Chin jako konkurenta. Świadczy o tym przygotowana ustawa (która w zasadzie przeszła przez wszystkie fazy legislacyjne), przewidująca obciążenie chińskiego eksportu do Stanów Zjednoczonych stawką celną przekraczającą 35\% (ad valorem) w przypadku nie dokonania przez Chiny rewaluacji yuana w granicach $35 \%$. To automatycznie kładzie eksport chiński i tu jawi się cały dylemat.

Nawiasem mówiąc, jeśli chodzi o podejście samej administracji, to jest tak jak mówił prof. Haliżak, że administracja jest za współpracą z ChRL i deklaruje traktowanie ChRL jako strategicznego partnera. Przypomnijmy natomiast, że w samym programie wyborczym Busha jego stanowisko było odmienne: Chiny zostały potraktowane jako konkurent. Rodzi się w związku z tym pytanie, czy zmiana podejścia w tej kwestii ma charakter koniunkturalny i wynika ze względów pragmatycznych, zrodzonych z realiów współczesnej gospodarki światowej, czy też ma charakter trwały, upatrując w Chinach partnera strategicznego. Tego dylematu nie rozstrzygną również następne wybory prezydenckie w 2008 roku. Ewentualne wahnięcia w jedną, czy drugą stronę będą miały również charakter średniookresowy, dyktowany względami pragmatycznymi, bo takie są realia współczesnej gospodarki światowej i towarzyszącej jej polityki.

Na koniec jeszcze jedna sprawa, a mianowicie problem koncepcji chińskiej zagranicznej polityki ekonomicznej i chińskiej międzynarodowej polityki ekonomicznej. Zagranicznej, gdzie państwo jest podmiotem i autonomicznie kształtuje swoje międzynarodowe stosunki gospodarcze i międzynarodowej - kiedy chodzi o funkcjonowanie na forum organizacji międzynarodowej, zaś podmiotem takiej działalności jest grupa państw. Nasza optyka pod tym względem, jak się wydaje, jest zbyt jednostronna. Patrzymy bowiem na chińskie działania w dziedzinie zagranicznej i międzynarodowej polityki ekonomicznej częściej przez pryzmat chińskich interesów na rynkach krajów rozwiniętych - jak mawiamy: Północy - zaś z pola widzenia gubimy aktywność ChRL w krajach Południa. Tymczasem „skrzydło południowe” nabiera coraz większego znaczenia w zagranicznej i międzynarodowej polityce ekonomicznej ChRL. To jest właśnie ta nowa jakość. Była tutaj mowa w tym kontekście o Azji Południowo-Wschodniej, ale przecież pojawiają się nowe kierunki - Afryka i dalej Ameryka Południowa. W Afryce strategia chińska, jak się wydaje, polega na zawojowaniu jej od strony ekonomicznej. Praktycznie już dzisiaj Chińczycy wyparli Amerykanów z Afryki - Amerykanie zajmowali tutaj pierwsze miejsce, stopniowo jednak wycofali się do innych krajów słabo rozwiniętych, w tym zwłaszcza do Ameryki Łacińskiej. Ale i tutaj jest wielka niewiadoma, co dalej będzie się działo. Czy Chińczycy wesprą ekonomicznie Evo Moralesa i Hugo Chaveza, przykładowo angażując się w rozwój sektora energetyki w Boliwii, czy też produkcji ropy naftowej w Wenezueli? To jest właśnie ten cały dylemat, cały ten problem, bo kluczowe znaczenie może mieć bowiem to, co w krajach Południa będzie się działo w kontekście coraz 
szerszego angażowania się ChRL na tych rynkach. I to może być właśnie tą nową siłą i przeciwwagą dla dotychczasowych biegunów rozwoju, o których tutaj mówił również profesor Rowiński.

\section{Jan Milewski ${ }^{5}$}

Nie mogę nie zacząć od wyrażenia najwyższego uznania panelistom. To, co panowie powiedzieli i to, jak to panowie powiedzieli, było naprawdę dla mnie - i, myślę, że dla wszystkich zebranych - wielkim przeżyciem intelektualnym. Teraz pytanie. Tutaj trochę mnie ubiegł profesor Starzyk, ale jesteśmy w tej sali sąsiadami, więc może w sąsiedztwie rodzi się podobne myślenie. Otóż, ja chciałem zadać następujące pytanie panom panelistom: jak w chińskiej myśli politycznej i jak w chińskiej długofalowej strategii wygląda Afryka? Przypomnę, że według prognoz Narodów Zjednoczonych, Afryka w połowie tego stulecia będzie prawdopodobnie najludniejszym regionem; szacuje się, że liczyć będzie - prognozy, jak państwo wiecie, są różne - między 1.4 a 1.7 miliarda ludności. I dopiero za nią będą dwa państwa: Chiny i Indie. Nie pytam oczywiście o obecną ekspansję gospodarczą Chin na terenie Afryki, o sprawy ropy afrykańskiej, rynków afrykańskich, bo to są sprawy znane. Moje pytanie dotyczy miejsca i roli Afryki w szerszym i głębszym wymiarze strategicznym.

\section{Karin Tomala}

Pracuję w Polskiej Akademii Nauk w Centrum Krajów Pozaeuropejskich, gdzie od wielu lat zajmuję się Chinami. Współpracuję też z Wyższą Szkołą Międzynarodowych Stosunków Gospodarczych i Politycznych w Gdyni. Powstała tam w ramach studium „Stosunki Międzynarodowe” specjalizacja CHINOZNAWSTWO - Studia o współczesnych Chinach. Może ten termin brzmi obco, ale jak się mówi „niemcoznawstwo”, dlaczego nie może być „chinoznawstwo”, tak potrzebne również w Polsce? Studia prowadzone są od roku 2004 we współpracy z Chińsko-Polskim Towarzystwem Okrętowym Chipolbrok. Sinologia natomiast, jak wiemy, stawia w swoim zainteresowaniu inne obszary ciężkości.

Cieszę się bardzo z tego spotkania. Chciałam wyrazić wielkie uznanie organizatorom, ale i prosić o kontynuację. Może nie co tydzień, ale gdybyśmy spotkali się cztery razy w roku na poważnych dyskursach i wymianie poglądów, byłoby to - uważam - bardzo pożyteczne. Wśród tematów naszego spotkania wymieniona była również kwestia stosunków miedzy Chinami i Europą. Stanowi to niezwykle ważne zagadnienie - nie tylko w polityce międzynarodowej Chin, lecz również dla polskiej polityki zagranicznej. Niestety, paneliści za mało uwagi poświęcili temu problemowi. Czy nie byłoby pożądanym zorganizowanie odrębnego panelu poświęconego zagadnieniom relacji między Unią Europejską a Chinami, uwzględniając stosunki z tym państwem wybranych krajów europejskich? Może również Fundacja „Polska w Europie”, współorganizator dzisiejszego panelu, mogłaby przedstawić swoją ocenę stosunków z Chinami?

5 Z uwagi na niedostarczenie przez dyskutanta autoryzowanego tekstu wystąpienia, publikujemy wersję nieautoryzowaną. 
Wypowiedzi, głoszone na tej sali, były naprawdę stymulujące i są warte pogłębienia. Chciałam podkreślić, że przecież jest wielka różnica między polityką wobec Chin Stanów Zjednoczonych i Unii Europejskiej, i dlatego stare chińskie przysłowie, który cytował profesor Rowiński, chyba nie jest tak całkiem na miejscu. Ja uważam, że Chiny nie tylko obserwuja, ale są przekonane, że polityka Stanów Zjednoczonych charakteryzuje się inną perspektywą niż strategia Unii Europejskiej. Mimo retoryki istnieją różne strategie. Za mało słyszałam o Europie, o naszej zachodniej cywilizacji. Analizując rozwój strategii Chin powinniśmy czynić to w sposób bardziej komparatywny. Mówię tu - oczywiście, w skrócie - aby uświadomić, iż nasza Europa, nasza cywilizacja nie bardzo rozumie Chiny. Może Chińczycy mają rację, gdy tak mówią. Takie postrzeganie naszej cywilizacji przez Chińczyków powtarzane jest prawie od stu lat. Jednakże tylko niewielu myślicieli naszej cywilizacji, jak filozofowie francuscy, amerykańscy czy też niemieccy, ma odwage nazywać naszą cywilizację po imieniu, jako ,samolubnie skostniałą". Dwa lata temu organizowano w Brukseli wystawę pod tytułem „Historia Europy”. Piękna impreza, rodzaj edukacyjnej, ale nie tylko. Wiemy, że twórcy lubią się bawić i, przede wszystkim, szokować - i przez to prowadzić do obudzenia świadomości ludzi. Na tej wystawie było bardzo dużo o historii Europy. Ale ciekawe było to, co widniało na jednej, przedostatniej tablicy. Tam napisane było, że Europa będzie się rozszerzała, a następnym jej wspólnym językiem będzie język chiński. Naturalnie to był żart, ale piękny żart, nawołujący do głębszej refleksji po to, żeby po prostu obudzić ludzi, uświadomić im, że tutaj, w tym regionie, coś się dzieje. Chińczycy twierdza, że Europejczycy, czy Amerykanie nie rozumieją, co się dzieje w Chinach, nie rozumieją Chińczyków. Warto, więc się zastanowić, dlaczego my, czyli nasza cywilizacja, my na Zachodzie, o wiele mniej wiemy o Chinach niż Chińczycy o nas. I to jest aspekt, którego nie wolno lekceważyć.

Jak można mówić o Chinach i nie zapytać, dlaczego jest taki, a nie inny rozwój? Niemcy, na przykład, mówią, że Polska jest dla nich zagadką. Ja uważam, że prawdziwą i największą zagadką w tej chwili są Chiny. Zgodziłabym się z tym, co pan profesor Rowiński powiedział: że Chiny obecnie nie stanowią zagrożenia. Według mnie prawdziwe globalne zagrożenie stanowi rodzaj nowej rywalizacji w świecie i wynikające $\mathrm{z}$ tego procesu niewiadome.

I może jeszcze jeden problem. Bardzo żałuję, że pan redaktor z „Gazety Wyborczej” już wyszedł, bo ja mam krytyczną uwagę pod adresem „Gazety Wyborczej”. Mówimy cały czas, że rozwój w Chinach jest niesamowity. Bardzo ubolewam na tym, co ta gazeta potrafi publikować o Chinach, jak często mętne poglądy. Przecież „Gazeta Wyborcza” to nie byle jaka gazeta - uznana gazeta, czytana w całej Polsce. A 90\% artykułów o Chinach nie oddaje tego, co dzieje się w tym kraju. Są one bardzo jednostronne i przez to nieodpowiedzialne. Wczoraj czytałam w „Rzeczpospolitej” artykuł o Chinach pióra pewnego Amerykanina. Też uważam go za bardzo mylący. Czasem można zamieścić $\mathrm{i}$ taki głos, ale w tej chwili potrzebujemy naprawdę rzetelnych informacji.

I ostatni punkt, na który pragnę zwrócić uwagę. Kilka razy stawiano tutaj pytanie: na ile kierownictwo w Chinach będzie w stanie rozwiązać problem rozwoju tego kraju? Trzeba tu pamiętać, i to pragnę podkreślić, że cały obecny rozwój jest wielkim eksperymentem, że sytuacja w Chinach nie jest stabilna, ale i też nie jest niestabilna - typowo 
po chińsku. Jednak, dopóki Chiny się nie rozpadną, a ja nie widzę takiego zagrożenia w następnych latach, uważam, że rozwój Chin oznacza dla nas wielkie wyzwanie, i to jest dobrze dla nas.

\section{Ryszard Piasecki}

Zostało dziś tutaj poruszonych wiele ważnych kwestii. Na przykład kwestia Konsensusu Waszyngtońskiego. Jest oczywistą sprawą, że jest on różnie oceniany. Na przykład w ONZ było ostatnio słynne wystapienie D. Rodrika, który dokonał ogromnej krytyki Konsensusu. Ale tu nie o to chodzi. Faktem jest, że twórca Konsensusu - zdrowo-rozsądkowego podejścia, bardzo normalnego, racjonalnego podejścia jak prowadzić gospodarkę - w oczywisty sposób pominął uwarunkowania kulturowe i instytucjonalne. Zakładał on, będąc Amerykaninem, że niezbędne warunki kulturowe i instytucjonalne są spełnione, po prostu istnieją dookoła nas. I tu jest bardzo ciekawe, jak to się dzieje, że w Chinach, gdzie nie są do końca uznawane czy uregulowane prawa własności, nie działają w pełni instytucje prawa, gdzie prawo jest dyskusyjne - wiemy, jakie - że ta gospodarka działa. Jest to, myślę, duża zagadka dla ekonomistów liberalnych, problem modelu gospodarczego.

Jest jeszcze jedna kwestia. Chiński model rozwoju - padła tutaj bardzo słuszna uwaga - jest już od 2005 r. poddawany korekcie. Już dzisiaj się mówi w Chinach o konieczności realizacji celów społecznych, o wyhamowaniu szybkiego tempa wzrostu gospodarczego, bo w sytuacji 80000 protestów społecznych, kraj ten ma po prostu poważne problemy. To jest $\mathrm{w}$ dalszym ciagu biedny kraj - mimo 1000 USD na głowę. To w dalszym ciagu jest kraj Trzeciego Świata, mimo, że Szanghaj wygląda imponująco. To jest duża sprawa - patrzeć na Chiny w sposób perspektywiczny, w którym kierunku ten kraj pójdzie, to problem fascynujący i bardzo ważny. Jeszcze jedna kwestia: obok pojawiaja się Indie. Mało tu mówiliśmy o Indiach, ale zakłada się - według różnych obliczeń, biorąc pod uwagę wzrost demograficzny - że w 2030 roku Indie ludnościowo przegonią Chiny. To jest kraj, który realizuje swoją politykę gospodarczą w sposób bardziej zbliżony do modelu rynkowego (mimo dużej interwencji państwa), ma instytucje demokratyczne, ma prywatną własność, itd. Kraj działa zupełnie inaczej. Kto wie, czy Indie nie okażą się za lat 20 czy 30 liderem Azji? Ale - już na koniec - ilekroć słyszę dyskusje na temat Afryki i Azji ciągle wracam myślami do Gunnara Myrdala - guru ekonomistów lat 60. Myrdal powiedział wtedy, że „wygra Afryka, a przegra Azja, bo Azja nie poradzi sobie z problemem żywnościowym". I co się okazało? Dokładnie odwrotnie. Jak widać, nawet wielcy ekonomiści mogą się mylić.

\section{Ksawery Burski}

Chciałbym podać najnowsze dane dotyczące gospodarki i dyskusji, jakie się toczą w Chinach. Otóż przywódca chiński Deng Xiaoping był świadom po swoich wizytach w Stanach Zjednoczonych, w Japonii oraz w Azji Południowo-Wschodniej pod koniec lat 70., że chińskie społeczeństwo i chińska cywilizacja i kultura są w stanie pewnego zastoju, i że potrzebne są nowe bodźce. Stąd polityka reform i otwarcia na świat. Dopuszczono 
te nowe bodźce, podjęto dziesiątki, jeśli nie setki najrozmaitszych reform. Sześć lat temu sinolog, ksiądz Malek, mieszkający w Niemczech, mówił w Krakowie, że w Chinach obserwujemy kakofonię reform. Nie wiemy, czym ta kakofonia się skończy, ta kakofonia jest tak silna, że niekiedy trudno rozpoznać główny nurt reform i prawidłowo ocenić, które z nich są ważne. Stąd chwała polskim sinologom i orientalistom, i wszystkim innym w Polsce, za to, że podejmują badania i obserwacje tego, co się w Chinach dzieje. W wyniku reform Chiny osiagnęły już bardzo wiele i dzisiaj wszyscy w Chinach - politycy, ekonomiści, politolodzy, socjologowie - zastanawiają się, co dalej. Według danych za ubiegły rok chiński PKB wynosił 2 biliony 262 miliardy dolarów, zaś handel zagraniczny 1 bilion 422 miliardy dolarów. Pytanie, co dalej? Jak Chiny powinny się dalej rozwijać? Chińczycy oceniaja, że przy obecnym układzie sił na świecie i przy stosunkach, jakie powstały w ostatnich 20 latach, Chiny zyskały historyczną szansę dogonienia świata, świata rozwiniętego. Dorównania tym, przede wszystkim, którzy przodują w sensie materialnym. Chiny postawiły sobie za cel renesans - odrodzenie chińskiej nacji. To jest na różne sposoby interpretowane - generalnie idzie przede wszystkim o rozwój gospodarczy, ale dzisiaj także o społeczny i kulturalny. Dyskusja, jaka się toczy dzisiaj w Chinach dotyczy modelu dalszego rozwoju. Chińczycy są świadomi, że dotychczasowy rozwój - co jeden z panów profesorów już podnosił - jak gdyby się wyczerpuje. Albo też inaczej - że nie spełnia on wszystkich oczekiwań, że sam wzrost PKB, sam rozwój gospodarczy nie wystarcza. Że trzeba zaspokoić także potrzeby społeczne, że ten rozwój powinien być bardziej harmonijny i zrównoważony.

Co przyczyniło się - i kto przyczynił się - do dotychczasowego wzrostu i dalszego wzrostu gospodarczego Chin? Chińczycy, po pierwsze, wprowadzili i wprowadzaja nadal kolejne elementy gospodarki rynkowej. Pozwolili części społeczeństwa na wcześniejsze bogacenie się, dochodzenie do dobrobytu. To był ten bodziec, który uruchomił pracowitość Chińczyków, bo przecież w latach 50. i 60. tego nie było. Mieliśmy „wielki skok”, mieliśmy „rewolucję kulturalną” i wiele innych rzeczy, i Chiny tkwiły w zastoju. Dopiero, kiedy część społeczeństwa uzyskała szansę dojścia do dobrobytu, kiedy dano mu znaczną swobodę, zliberalizowano system i polityczny, i gospodarczy, wtedy uwolniona została tradycyjna chińska pracowitość. Ale to nie wystarczyło. Chińczycy mogli korzystać z doświadczeń Japonii, która zaczęła modernizację w latach 60. XIX w., następnie z doświadczeń rozwoju i modernizacji Południowej Korei, która dokonała skoku po zakończeniu wojny w ciagu 30-40 lat - ale pamiętajmy, że tam pracowano po 12 godzin na dobę i nie był to jeszcze w owych latach kraj wzorujący się na zachodnich demokracjach. Następnie przywódcy chińscy poznali osiagnięcia Singapuru i Malezji. Singapur był najlepszym przykładem, bowiem jego społeczeństwo, to naród w większości o chińskich korzeniach. Jeżeli mógł wiele osiagnąć Singapurczyk-Chińczyk w Singapurze, to może tego dokonać i Chińczyk w ChRL. Wieloletni premier Singapuru, Lee Kuan Yew, wielokrotnie objaśniał gościom z Pekinu mechanizmy funkcjonowania i źródła sukcesów swego kraju. W pewnym okresie był wręcz doradcą rządu chińskiego i w podobnych rolach pojawiało się w Chinach kilku byłych ministrów i innych wyższych urzędników singapurskiej administracji gospodarczej. W pewnym momencie Deng Xiaoping wręcz zalecił ,uczenie się od Singapuru”. Opisując czynniki, które wpływały 
na tak przyspieszony rozwój Chin nie można pominąć faktu, że w Chinach zainwestowano ponad bilion dolarów obcych pieniędzy, ale na pierwszym miejscu wśród tych obcych pieniędzy jest kapitał hongkoński. Na drugim jest kapitał tajwański, na trzecim - kapitał emigracji chińskiej. W Chinach powstały całe nowe gałęzie, których tam dawniej nie było (bądź były słabe) jak przemysł samochodowy, elektroniczny, stoczniowy, maszyn rolniczych, papierniczy, AGD, meblarski, obuwniczy i wiele innych. Niekiedy po prostu przeniesiono je z Hongkongu, przeniesiono je z Tajwanu, z Tajlandii, Singapuru, z Malezji. Przenieśli je ludzie, inżynierowie i technicy mówiący tym samym językiem, którym mówi chiński technik i inżynier, i robotnik, którzy mogli przekazać nie tylko technologię, ale i sposób zarządzania. Oczywiście w ślad za tym kapitałem przyszedł kapitał amerykański, przyszedł zachodnio-europejski, japoński, południowo-koreański. Największą zasługę w tej modernizacji, tym skoku cywilizacyjnym Chin, oprócz Deng Xiaopinga i jego ekipy ma właśnie patriotyczna chińska emigracja, Chińczycy z Hongkongu i Tajwanu. To oni tworzyli i nadal tworzą wzorce do naśladowania. Ale jeśli idzie teraz o świat zewnętrzny - Chiny na pierwszym miejscu dzisiaj stawiają stosunki ze Stanami Zjednoczonymi, ponieważ stamtąd uzyskują najwięcej nadwyżek w obrocie towarowym (w 2005 r. wg chińskich danych było to 114 mld dolarów zaś wg danych amerykańskich aż 202 mld dol.) przeznaczanych do wspierania dalszej modernizacji i rozwoju. Na drugim miejscu jest Unia Europejska. A dlaczego Unia Europejska? Po pierwsze, Unia od ubiegłego roku, właściwie od 2004 roku, jest pierwszym partnerem handlowym Chin - w ubiegłym roku było to 217 miliardów dolarów; w Unii największym partnerem są Niemcy (w 2005 r. 63 miliardy dol.), na drugim miejscu Holandia (28 mld), potem Wielka Brytania (24 mld). Drugim partnerem handlowym są Stany Zjednoczone - 211 mld, na trzecim miejscu jest Japonia - 184 miliardy. We wszystkich przypadkach chiński eksport rósł w $2005 \mathrm{r}$. o $23-25 \%$, chiński import z tych obszarów o $5-9 \%$. Chiny oceniają świat, oceniają poszczególne kraje według tego jak dany kraj może przyczynić się do modernizacji Chin, do przyspieszenia ich wzrostu. Każdy kraj, który oferuje Chinom nowe technologie, nowa wiedzę, nowe pieniądze bądź surowce jest traktowany priorytetowo. Do niedawna najwyższym priorytetem były dobre stosunki ze Stanami Zjednoczonymi. Dzisiaj część politologów chińskich to kwestionuje. Uważają, że na pierwszym miejscu trzeba postawić stosunki z sąsiadami. Chiny chcą mieć pokojowe otoczenie, a przecież punktem zapalnym jest Cieśnina Tajwańska, punktem zapalnym jest Północna Korea, mógł być też Kaszmir i był Afganistan, w pewnym sensie. Chinom zależy na tym, żeby nie marnować nadmiernej ilości środków na zbrojenia, na zabezpieczanie się. Oczywiście, bezpieczeństwo szlaków żeglugowych itp. to są wszystko sprawy ważne, dzisiaj wszakże najważniejszy jest rozwój.

Ekonomiści i politolodzy chińscy debatują zacięcie na wszystkie te tematy, które tu dzisiaj były podejmowane i można znaleźć tego potwierdzenie na łamach chińskiej prasy ekonomicznej i politologicznej, jak również w czasopismach i książkach. Chińczycy sprzeczają się o to, czy ważniejszą sprawą jest dobrobyt społeczeństwa, czy ważniejszą sprawą jest międzynarodowa pozycja kraju, czy wzrost Chin do pozycji mocarstwa jest zadaniem numer jeden, czy też dobrobyt całego społeczeństwa powinien być zadaniem numer jeden dla obecnego rządu i dla przyszłych rządów. Te debaty są tam bardzo ostre 


\section{$150 \quad$ Chiny - Unia Europejska - Stany Zjednoczone...}

i, muszę powiedzieć, że niekiedy ukazują wręcz jak głęboko Chińczycy znają swoje sprawy i swoje problemy, również jak szeroko znają świat.

Wracając jeszcze do Unii Europejskiej, otóż Unia obok handlu i obok inwestycji w Chinach jest najważniejszym źródłem nowych technologii w Chinach. Unia jest najbardziej hojna, jest hojniejsza niż Japonia, hojniejsza niż Stany Zjednoczone. Ale Chiny nie gardzą też technologią z innych krajów - z Wenezueli, z Malezji, z Singapuru, z Australii. Każdy kraj, który może im coś dobrego zaoferować jest mile widziany, z każdym takim krajem chcą mieć dobre stosunki. Kiedy przyjeżdżali do Pekinu komisarze unijni - do spraw nauki, oświaty i kultury i innych - i prezentowali jak Chiny włączają się do programu Galileo, do budowy koncepcji Galileo, jak włączają się do ramowego programu badań naukowych w Unii, to pod adresem chińskich naukowców przyjeżdżających do Europy padały z ich strony liczne pochwały, wręcz komplementy. Chińczycy przyjeżdżający do Europy - każdy z naukowców zna biegle jeden, bądź dwa, czasami trzy języki europejskie - są w stanie wejść do Instytutu Atomowego pod Paryżem, czy jakiegokolwiek innego we Włoszech, czy w Niemczech i włączyć się do pracy, bo znają język, są dobrze przygotowani. Ja zadawałem wtedy pytania czy odbywa się to na zasadzie wzajemności, tzn. czy europejscy naukowcy, inżynierowie przybywający do Chin znają na tyle język chiński, by podjąć pracę, badania. Moje pokolenie zna głównie język polityczny i ekonomiczny, dzisiaj natomiast wypadałoby znać także język nauk ścisłych, technicznych. Być może na polskich politechnikach powinniśmy zacząć nauczać języka chińskiego, także w zakresie nauk ścisłych i technicznych. Uważam, że postęp, jaki się u nas dzieje w dziedzinie popularyzacji wiedzy o Chinach jest wyraźny, ale niewystarczający. Sądzę, że powinniśmy mieć więcej ośrodków, powinniśmy lepiej znać Chiny, rewanżować się naszym chińskim przyjaciołom za ich wiedzę o naszym kraju, o Europie. Dziękuję bardzo za uwagę. Dziękuję organizatorom za pomysł i popieram sugestię pani profesor Tomali, żeby takie spotkania odbywały się częściej.

\section{Edward Haliżak}

Jedną z istotnych kwestii tu podnoszonych jest przyszłość Korei. Jest to problemem naprawdę kluczowym. Ale musimy odpowiedzieć na podstawowe pytanie: czyim sojusznikiem byłaby ewentualna zjednoczona Korea - Rosji, Chin, Japonii czy Stanów Zjednoczonych? I taką opcję musieliby zaakceptować inni partnerzy. Jeżeli to zostanie rozstrzygnięte, znajdzie się formuła zjednoczeniowa. Jeżeli nie - to Koreańczycy będą podzieleni jeszcze na bardzo długo. To jednak będzie groziło wzrostem nacjonalizmu. Wedle wszelkich wiarygodnych opinii na Południu Korea Północna cieszy się sporym zaufaniem, fascynuje miejscowych narodowców, a głośny program nuklearny to nawet nasila. Nacjonaliści na Południu mówią: „My mamy potęgę ekonomiczną i technologię, a Północ ma broń jądrową. Po zjednoczeniu będziemy siódmą gospodarką w świecie i będziemy dysponować bronią jądrową". W związku z tym wzrost nacjonalizmu koreańskiego po obydwu stronach należy brać pod uwagę bardzo poważnie. Być może Stany Zjednoczone i inne mocarstwa w pewnym momencie zaniepokoją się tą sytuacją na tyle, 
by szukać jakichś trwałych rozwiązań. Na razie mamy tam ostatni nierozwiązany konflikt z epoki zimnej wojny.

\section{Jan Rowiński}

Krótko, w kilku zdaniach, odniosę się do niektórych poruszonych w dyskusji problemów. Odnośnie uwagi profesora E. Haliżaka o polityce USA wobec Chin po drugiej wojnie światowej. W moim przekonaniu podstawowy błąd, który popełnili Amerykanie, (a później powtórzyli go Rosjanie), polegał na tym, iż nie chcieli zrozumieć, że Chiny nigdy i wobec żadnego państwa nie zaaprobują roli „młodszego brata” - xiao didi.

$\mathrm{Na}$ marginesie wystapienia profesora K. Gawlikowskiego. Moim zdaniem, procesy globalizacji i regionalizacji są nieuchronne i nieodwracalne. Wielu badaczy koncentruje się na ich negatywnych aspektach, ale nie należy zapominać i o ich pozytywnych stronach, w tym zbliżenia i dialogu międzycywilizacyjnego, elementu składowego budowy cywilizacji globalnej i procesu swoistej konwergencji, łączenia tego co najlepsze na Wschodzie i na Zachodzie, żeby móc efektywniej stawić czoła tym wszystkim gigantycznym wyzwaniom przed którymi stoi ludzkość.

Przy całym szacunku dla „wielkiego skoku modernizacyjnego "dokonanego przez Azję w II połowie XX wieku byłbym ostrożny wobec powtarzanych jak mantra zaklęć (prognoz), że „XXI wiek jest wiekiem tego kontynentu.”

Sadze, iż jednym z najbardziej interesujących zjawisk, jakich jesteśmy świadkami to narodziny i kształtowanie nowej chińskiej ideologii państwowej. Ujawniają się przynajmniej cztery bardzo wyraźne jej składniki: „powrót do korzeni” kulturowo- cywilizacyjnych, wielkiej tradycji (heritage) wartości konfucjańskich i nauk innych wielkich myślicieli Państwa Środka, prób odczytania i interpretowania ich na nowo, sunjatsenizm i być może dengizm - jako droga modernizacji Chin i otwarcia na świat, łączenia osiagnnięć Zachodu z wielkim własnym dorobkiem, nacjonalizm, o którego źródłach tutaj mówiono, oraz „chiński socjalizm”, odchodzący od maoistowskiej aberracji i wyraźnie ewoluujący w kierunku jakiejś formuły socjaldemokratycznej o chińskich cechach charakterystycznych. Dziś podstawowym elementem legitymizacji władzy w ChRL i warunkiem jej utrzymania przez rządzących jest postęp gospodarczy, stabilizacja polityczno- społeczna i wzrost międzynarodowej pozycji kraju, realizacja jego aspiracji.

I jeszcze jedno podstawowe pytanie dotyczące stosunków Chin i Japonii. Od tego jak się będą układały zależy przyszłość Azji Wschodniej i szansa jej integracji. To prawda, iż nigdy nie były równocześnie potęgami. Historia dowodzi, że państwa niemniej zantagonizowane w historii (np. Niemcy i Francja, Niemcy i Polska, Polska i Rosja), szukaja i nie bez meandrów i trudności znajdują drogi przezwyciężania historycznych animozji, wrogości i uprzedzeń.

I na koniec chcę powiedzieć, iż z pokorą przyjmuję krytykę pod moim adresem, iż zbyt pobieżnie potraktowałem główny temat swego wprowadzenia poświęcony relacjom europejsko-chińskim, dlatego w jego pisemnej wersji staram się ten błąd naprawić. Dziękuję bardzo. 


\section{$152 \quad$ Chiny - Unia Europejska - Stany Zjednoczone...}

\section{Henryk Szlajfer}

Chciałbym podtrzymać tezę, że Azja Wschodnia, wraz z Chinami, jest regionem charakteryzowanym przez stosunkowo wyraźnie zaakcentowaną niestabilność geopolityczną. Jest tak, mimo iż większość z ,aktorów”, wraz z Chinami, stara się umocnić stabilizację. Jednak typ interesów, sposób ich realizacji i brak - jak podkreślałem - elementów zaawansowanej instytucjonalizacji umożliwiających rozładowanie lub łagodzenie napięć, sprawia, że dobre intencje „aktorów” - a nie zawsze są one rzeczywiście dobre - mogą w istocie zwiększać niestabilność. Nie oznacza to jednak, że musi tam dojść do dramatycznego załamania. Azja Wschodnia stanowi region, który jeszcze długo nie będzie można określać jako „uspokojony” czy stabilny.

Druga kwestia dotyczy społecznej polaryzacji. Podkreślam: nie jestem ekspertem „od Chin”, mogę tu tylko korzystać ze swej wiedzy dotyczącej innych regionów świata, w szczególności Europy czy Ameryki Łacińskiej. Taki system, jaki powstaje obecnie w Chinach, niegdyś - mniej więcej 40 lat temu - określano w odniesieniu do Brazylii nie jako budowanie nowoczesnego państwa i gospodarki, lecz Belindii - połączenia dobrobytu małej Belgii z nędzą wielkich Indii. Innymi słowy, mówimy o systemach niezwykle spolaryzowanych, co nie musi, oczywiście, nieuchronnie prowadzić do gwałtownych społecznych i politycznych wstrząsów. Natychmiastowa rewolta biednych przeciwko bogatym nie czai się za progiem, ale systemu silnie spolaryzowanego nie można uznać za stabilny. Elementem tej polaryzacji jest rosnąca (prawdopodobnie) przepaść między miastem a wsią. W przypadku Chin będziemy mieli do czynienia z niezwykle prężnym, zmodernizowanym $\mathrm{w}$ wielu sektorach państwem, w którym stopień urbanizacji będzie dość ograniczony. Rozziew między imponującym ogólnym poziomem rozwoju a innymi wskaźnikami ukazującymi położenie społeczne i gospodarcze poszczególnych grup społecznych będzie narastał. Mam tu na myśli chińskich chłopów i rozwiązanie „problemu wsi”. W jaki sposób? Nie wiem.

\section{K. Gawlikowski}

Na zakończenie może warto przypomnieć drogę, jaką przeszły Chiny. W świecie cywilizacji agrarnych przodowały jako kraj najwyżej rozwinięty, z systemem politycznym państwa proto-nowoczesnego, wyprzedzającego daleko współczesne im państwa Europy. Ponadto wytworzone tam mechanizmy kulturowe, polityczne i społeczne umożliwiły im przetrwanie - jako jedynemu, wielkiemu imperium starożytnemu - aż do naszych dni. Jest to nie tylko najdłużej istniejące państwo świata, ale też organizujące przez tysiąclecia najliczniejszą ludność, obecnie ponad jedną piątą całej ludzkości, prawie tyle co w Europie i obu Amerykach. Wedle szacunków, u progu rewolucji industrialnej w Europie Chiny produkowały bez mała jedną trzecią PKB świata.

Bolesne zderzenie z nowoczesnymi państwami Zachodu, wkraczającymi na drogę kapitalizmu i podbojów kolonialnych Azji i Afryki, doprowadziło do załamania tradycyjnego systemu Chin i najgłębszego kryzysu w ich dziejach. Na początku XX w. obce wojska robiły tam, co chciały i dyktowały warunki. Symbolem tych czasów poniżenia i rasistowskiej pogardy stały się sławne tabliczki z Szanghaju - zarządzanego w praktyce 
przez konsula brytyjskiego - „wprowadzanie psów i Chińczyków surowo wzbronione” wiszace rzekomo na tamtejszym eleganckim parku ,dla białych” (w innej wersji: na restauracjach dla „białych”). Jak pokazują badania, dokładnie takich tabliczek nie wieszano, psy rozdzielano jednak od Chińczyków i jest to tylko „patriotyczna legenda”, ale tak te czasy utrwaliły się w pamięci narodowej. Jest faktem, że nawet najbogatszy Chińczyk nie miał wtedy wstępu nawet w swoim kraju do klubu, czy restauracji „dla białych”. Jeszcze do czasów rewolucji kulturalnej podobne restrykcje obowiązywały w kolonialnym Hongkongu, a sławny Bruce Lee boleśnie przeżywał w latach sześćdziesiątych w Kalifornii dyskryminację ,żółtych” (obok lepiej znanej wobec „,zzarnych”). Dopiero za czasów Mao bycie Chińczykiem zaczęło budzić dumę.

$\mathrm{Na}$ początku lat dwudziestych ubiegłego wieku, kiedy Chiny przechodziły wojny domowe i burze rewolucyjne, kryzys osiagnął dno: śmiertelność niemowląt sięgała nawet 500 na 1000 żywych urodzin, a ludzie umierali z głodu setkami tysięcy. Na łamach ówczesnych chińskich czasopism dla inteligentów dywagowano, jak ochronić naród od wymarcia i unicestwienia. Wydawali się bowiem wielu chińskim patriotom „rasą skazaną na wymarcie" jak dziwaczne pandy. Wielki Kang Youwei (1858-1927), by przywrócić swym rodakom godne miejsce w świecie, rozważał nawet, jak doprowadzić do ich „wybielenia” i utworzenia sprawiedliwego „państwa globalnego” w duchu konfucjańskim 6 .

Meandry historii Chin były zadziwiające. Obalenie cesarstwa i ustanowienie pierwszej w Azji republiki, z demokracją parlamentarną (1911 r.), doprowadziły do totalnego chaosu i rządów soldatesek. Pewną stabilność przywrócono dopiero pod totalitarną, acz skorumpowaną, dyktaturą wojskową Guomindangu (Kuomintangu, 1928). Potem stały się one polem brutalnej agresji japońskiej i teatrem wielkich zmagań II wojny światowej (od 1931 r.). A po niej, w rezultacie kolejnej wojny domowej, „dyktatura czerwona” zastapiła „białą” (w 1949 r.), ale i zapewniła ona - po raz pierwszy od półwiecza - stabilność polityczną i przysłowiową „miskę ryżu” każdemu, zaprowadziwszy w kraju elementarny porządek. Oferowała ona nie tylko kult Mao, o czym nazbyt często u nas się zapomina, ale także budowę przemysłu, powszechną oświatę, równouprawnienie kobiet, awans klas niższych, a nawet elementarne prawa człowieka, choć tego terminu wówczas oczywiście nie używano. Nade wszystko zaś Chińczycy odzyskali wówczas wiarę w swoje siły i poczucie godności narodowej. Rozmaite elementy negatywne polityki maoistowskiej kumulowały się jednak osiagnąwszy apogeum podczas osławionej rewolucji kulturalnej

Dopiero po śmierci Mao Zedonga (1976) stały się możliwe wielkie reformy Deng Xiaopinga. Wyrwały one kraj z osobliwej, niemal całkowitej samoizolacji i zainicjowały trwający do dziś skok cywilizacyjny: od dominującej wciąż cywilizacji agrarnej i mentalności chłopskiej do świata nowoczesnego i post-nowoczesnego. Chiny nie tylko rozwijać się zaczęły najszybciej na świecie, ale przechodziły też fundamentalną modernizację i pospieszną okcydentalizację we wszystkich dziedzinach, od budowy po raz pierwszy w ich dziejach państwa prawa typu zachodniego, do upowszechniania seriali

6 Patrz: K'ang Yu-wei, Ta T'ung Shu - The One World Philosophy, przekł. Laurence G. Thompson, G. Allen \& Unwin, London 1958. 
amerykańskich i mód. Umożliwiał to stopniowy demontaż specyficznego „koszarowego komunizmu" Mao w bolszewicko-konfucjańskim stylu.

Awans Chin z pozycji pariasa i nędzarza do rangi drugiego - po Stanach Zjednoczonych - mocarstwa pod koniec XX w., i kraju wchodzacego do „cywilizacji konsumpcyjnego dobrobytu", stanowi - być może - obok rozpadu systemu kolonialnego i odzyskania niepodległości przez wszystkie narody, najdonioślejszą przemianę ubiegłego stulecia, z perspektywy nie dziennikarskich doniesień, ale procesów fundamentalnych „długiego trwania”. Konsekwencji tej zmiany nie jesteśmy chyba jeszcze w stanie docenić. Ale w ich tle wciąż znajduje się duma $\mathrm{z}$ dawnej glorii i bolesna pamięć tak niedawnego poniżenia narodowego, mobilizujące do wielkich wysiłków nie tylko polityków, ale i społeczeństwo. One też objaśniają, dlaczego solidarność i duma narodowa odgrywają tak wielką rolę w Chinach współczesnych, co budzić może pewien niepokój nie tylko wśród sąsiadów, ale także w Stanach Zjednoczonych i Unii Europejskiej, nienawykłych wciąż do nowych relacji partnerskich z Chinami i konieczności liczenia się z ich opiniami oraz interesami.

Schyłek bezdyskusyjnej i bezwzględnie egzekwowanej dominacji Zachodu, wraz z awansem cywilizacyjnym Azji Wschodniej, będzie miał niewątpliwie skutki nie tylko w sferze polityczno-strategicznej, ale także w sferze ducha i kultury. Czeka nas wielka rewolucja w sferze terminologii i koncepcji nauk społecznych, ukształtowanych przecież na bazie wyjątkowych zupełnie doświadczeń historycznych i tradycji Zachodu. Trzeba będzie dostosować ich kategorie i tezy do zupełnie innych doświadczeń Azji. Będziemy się musieli pogodzić z istnieniem innych struktur wartości, koncepcji człowieka, jego relacji z państwem, miejsca religii, itd. Wcześniejszy awans Japonii, pretendującej do miana „,najwierniejszego ucznia Zachodu” i czującej się jego posłuszną „młodszą siostrą”, miał implikacje bardzo ograniczone w tej sferze. Chiny stawiają nas w obliczu wyzwań o wiele donioślejszych, gdyż budzą nowe aspiracje w całym regionie. Przykładem może być choćby lansowana przez przywódców Singapuru i Malezji koncepcja „wartości azjatyckich”, czy idea „demokracji personalistycznej”, w duchu konfucjańskim, wiążącej jednostkę ze społeczeństwem, jako lepszy model polityczno-społeczny wypracowany przez badaczy z Korei Południowej ${ }^{7}$. Amerykanin Roger T. Ames dokonując syntezy teorii Johna Deweya i Konfucjusza - proponuje model „demokracji komunikatywnej” opartej na wspólnotach ${ }^{8}$. Zaczyna upowszechniać się na Zachodzie buddyzm wprowadzający zupełnie inną wizję życia. Świat u końca XXI w. będzie zapewne wyglądał zupełnie inaczej niż dziś, a zanik dominacji Stanów Zjednoczonych może mieć wiele wymiarów.

Dzisiaj możemy tylko stawiać rozmaite pytania. Jaka będzie przyszłość Zachodu i jak będzie się on zmieniał? Czy czeka go los Wielkiej Brytanii, niegdyś supermocarstwa, nad władaniami którego słońce nie zachodziło, a dziś ograniczonej do Wysp i cierpiącej

7 Chang Yun-Shik, Mutual Help and Democracy in Korea, [w:] D. A. Bell, H. Chaibong, red., Confucianism for the Modern World, Cambridge University Press, Cambridge - New York, 2003, str. 90-123.

8 David L. Hall, Roger T. Ames, The Democracy of the Dead: Dewey, Confucius, and the Hope for Democracy in China, Open Court, Chicago 1999. 
na zalew imigrantów z byłego imperium? Czy będziemy umieli ułożyć stosunki partnerskie z Azjatami i pogodzimy się, że swoje życie mogą układać oni wedle swoich potrzeb i wyobrażeń, a nie według miarek i pragnień ludzi Zachodu? Jak będzie wyglądać Azja i świat oparte na dialogu i współpracy cywilizacji? Jak przebiegać może zanik kulturowej dominacji Zachodu, czy - jak mówią Azjaci - jego „imperializmu kulturowego”? Czy procesy globalizacji i uniwersalizacji zdominują życie międzynarodowe, czy też ważniejsze od nich okażą się nowe nacjonalizmy?

To oczywiście pytania nie na dziś, i może nie na jutro, ale na przyszłe dziesięciolecia. Jest jednak jasne, że procesy globalizacji, zainicjowane pod parasolem dominacji amerykańskiej, dzisiaj sprzyjają już w większym stopniu odradzaniu się gospodarek azjatyckich, Chin, Indii i wielu „mniejszych tygrysów”. Właśnie pilna potrzeba skutecznej konkurencji z nimi - w perspektywie strategicznej - Stanów Zjednoczonych i Unii Europejskiej dodaje ich obecnym stosunkom z Chinami szczególnego dramatyzmu.

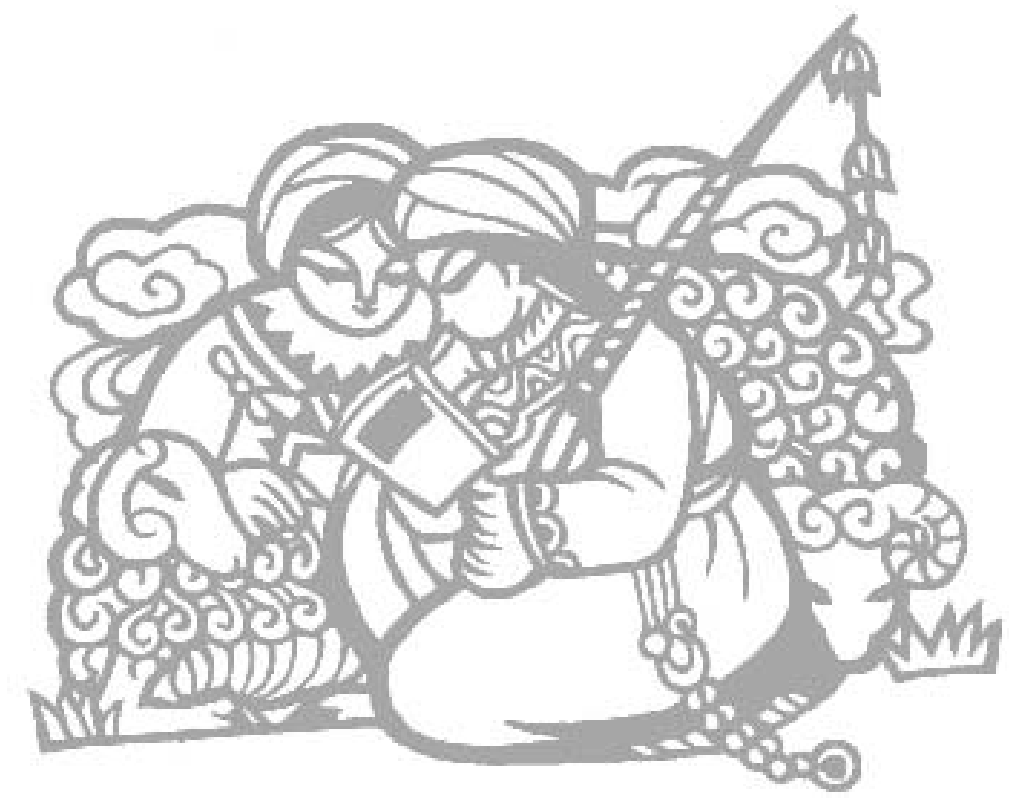

